\title{
Physiological and Psychological Effects of Walking in Urban Parks and Its Imagery in Different Seasons in Middle-Aged and Older Adults: Evidence from Matsudo City, Japan
}

\author{
Prita Indah Pratiwi ${ }^{1,2}\left(\mathbb{D}\right.$, Qiongying Xiang ${ }^{2}$ and Katsunori Furuya ${ }^{2, *}$ (1) \\ 1 Department of Landscape Architecture, Faculty of Agriculture, IPB University (Bogor Agricultural \\ University), Jalan Raya Dramaga, Bogor 16680, Indonesia; pritaindahpratiwi@ymail.com \\ 2 Department of Environmental Science and Landscape Architecture, Graduate School of Horticulture, Chiba \\ University, 648 Matsudo, Matsudo-shi, Chiba 271-8510, Japan; xiang.q@chiba-u.jp \\ * Correspondence: k.furuya@faculty.chiba-u.jp; Tel.: +81-47-308-8884
}

Received: 19 April 2020; Accepted: 6 May 2020; Published: 13 May 2020

\begin{abstract}
The benefits of park therapy have been investigated in young adults, but rarely for middle-aged and older adults. This study evaluates the physiological and psychological effects of walking in urban parks and park therapy images in winter, spring, and early summer. The experiments were implemented in two walking courses in the urban park in Japan and involved 12 middle-aged and older adults. Participants walked on walking courses in an urban park and city street for 11-15 min. Their heart rate and blood pressure were evaluated to determine physiological responses. The Profile of Mood States (POMS), State-Trait Anxiety Inventory (STAI), and Landscape Image Sketching Technique (LIST) were used to determine psychological responses and spatial conditions. Walking in an urban park exhibited lower heart rates and blood pressure as compared to walking in the city. It was congruent with lowered negative moods, total mood disturbance (TMD) scores, and state anxiety, while the higher positive mood was observed in the urban parks as compared to the city. Images in winter displayed trees, relaxation, and comfort; in spring, water, activity, people, surrounding place, and recreational space; and in early summer, greenery, lawn, and broadness. In conclusion, walking in urban parks leads to physiological, psychological relaxation, and varied landscape appreciation.
\end{abstract}

Keywords: walking; park therapy; heart rate; blood pressure; profile of mood states; state-trait anxiety inventory; landscape image sketching technique

\section{Introduction}

With concerns about urbanization diminishing contact between humans, nature, and public health, urban dwellers seek effective and convenient methods to resolve urban stress. Forest therapy is a set of practices that involve exposure to natural stimuli by practicing physical activity or relaxation in and around forest. This practice aims to regenerate immunocompetence through plant-derived physiological effects of relaxation [1]. Many studies have investigated physiological and psychological relaxation effect on young adults related to walking and viewing in urban parks and forests. Physiological studies have demonstrated the benefits of park and forest environment on decreased pulse rate [2,3], blood pressure [2-4], heart rate [4-10], salivary cortisol concentration [3,11], and increased parasympathetic nervous activity [2,4-10]. Moreover, psychological studies have exhibited the merits on improved subjective evaluations of comfortable, natural, relaxed, vigorous, 
calm, refreshed feeling [2-11], restoration and vitality [12], reduced negative moods (e.g., tension, anger, fatigue, depression, confusion), and state anxiety [4,6-10].

In a study of older adults, forest therapy resulted in physiological and psychological relaxation. Chen et al. reported that two-day forest recreation decreased systolic blood pressure and negative emotions (e.g., anger-hostility, confusion, fatigue, tension) among a middle-aged female group [13]. Conducting various activities of forest therapy for four hours decreased systolic and diastolic blood pressure, urinary adrenaline, and serum cortisol levels [14]. Li et al. investigated the effects of 80-min walking each in the morning and afternoon and reported that urinary dopamine after forest bathing was lower than that after urban area walking and serum adiponectin after the forest bathing was greater than that after urban area walking [15]. Moreover, a two-hour short walk in the forest decreased pulse rate, systolic and diastolic blood pressure, and reduced negative emotions (e.g., anger, confusion, depression, tension, fatigue), anxiety, and improved positive emotion [16]. Song et al. also reported the effects of viewing a forest environment on middle-aged hypertensive men for only $10 \mathrm{~min}$ that parasympathetic nervous activity enhanced, yet heart rate alleviated in participants viewing the forest area than in those viewing the urban area [17]. Recently, middle-aged and older adults have been used as subjects for hospital rooftop forest and garden therapy [18,19], urban gardening [20,21], horticultural therapy [22], park therapy [23,24], and community-based physical activity at parks [25]. Even within a compact city, all of these are valuable natural environments.

Spatial cognition of experienced landscape is yet to be examined through park therapy programs. By objectifying landscape image as visual information, the variation of participants' perception could be identified to possibly reveal spatial preferences and attractiveness of specific landscape elements. Previous studies exhibited distinctive characteristics of forests in Japan, Germany, Russia, and Indonesia [26-28], presenting factors that influenced perception, i.e., gender, age, past and present landscape type in the region of stay, past and present urbanization level, and experience of journey [28]. Kohori et al. determined the classifications of spatial configurations of historical green open spaces in Indonesia known as alun-alun or park squares through landscape images [29]. Ueda and Takayama also described the expected spatial conditions in a forest atmosphere that behavior and mood have corresponding landscape composition types and spatial conditions [30]. It would be necessary to develop an integrative examination of physiological and psychological beneficial impacts of walking in the urban park and park imageries in winter, spring, and early summer that might improve sustainable park development.

The aim of the present study is to elucidate the physiological and psychological effects of walking in urban parks and park therapy images in winter, spring, and early summer. Our detailed objectives are as follows: (1) to clarify the physiological and psychological effects of walking; (2) to analyze park therapy images; and (3) to analyze correlations between park therapy images and physiological-psychological responses in an urban park in winter, spring, and early summer. The hypothesis in our study was that a brief walk could induce the physiological and psychological relaxation of participants in an urban park; park therapy images would correlate with reduced physiological and psychological parameters of negative moods and state anxiety, as well as increased positive mood.

\section{Research Design}

\subsection{Experimental Sites}

The field experiment was performed from January to June 2019 in Forest and Park for the 21st Century (experimental site) and roadside of Mito Highway Route 6 (control site) in Matsudo, Chiba Prefecture, Japan (Figures 1 and 2). Forest and Park for the 21st Century (FPC) is a general park comprising an area of 50.5 hectares built to protect and raise the nature of Sendabori area. The best-known spots of this park consisted of Sendabori pond, Midori no Sato (Village of Green), Gathering Square, Hill for Getting Close to Green, Jomon no Mori, Light and Wind Square, Wild Grass Garden, and Flower Garden. Two walking routes, Midori no Sato (Village of Green)-Gathering Square in winter 
and early summer, and Park Center-Nature Observation in spring, were utilized in this study. Selection criteria for the walking course included: (1) minimum one-trip length of $400 \mathrm{~m}$; (2) flat slope; and (3) significant trees along the course. Changes in walking courses for each season were based on landscape elements that could be appreciated, such as cherry blossoms in spring, and typical Japanese deciduous and broad-leaved forests in winter and summer. The walking distance of winter and summer courses was $1.2 \mathrm{~km}$. The length of the walking course in spring was $800 \mathrm{~m}$. The average walking speed was around $1.3 \mathrm{~m} / \mathrm{s}$. We selected and set suitable walking times of $15 \mathrm{~min}$ maximum for winter and early summer. Walking at the same average speed, the spring course could be completed in $11 \mathrm{~min}$. The details regarding experimental sites are presented in Table 1.

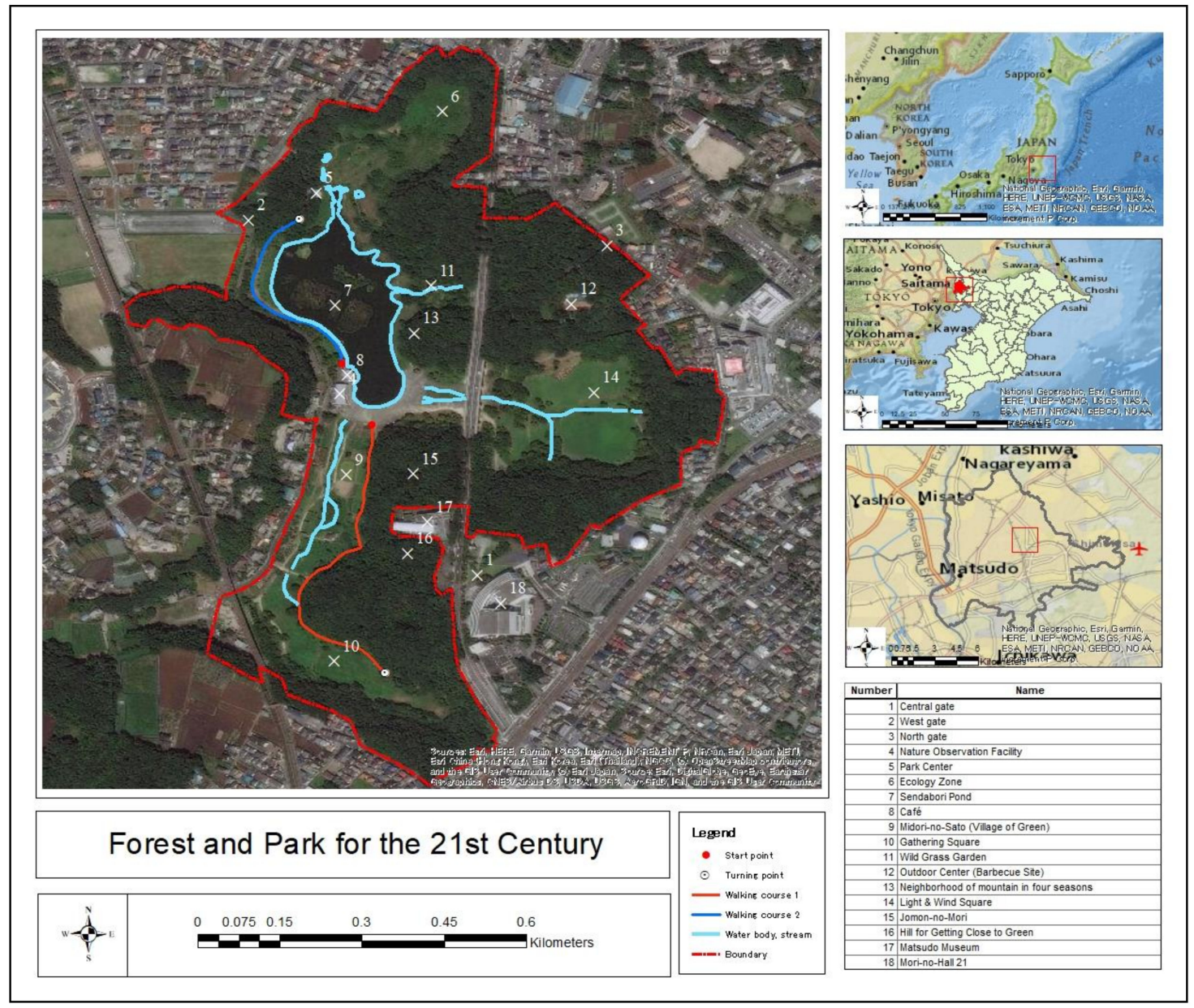

Figure 1. Experimental site map. 


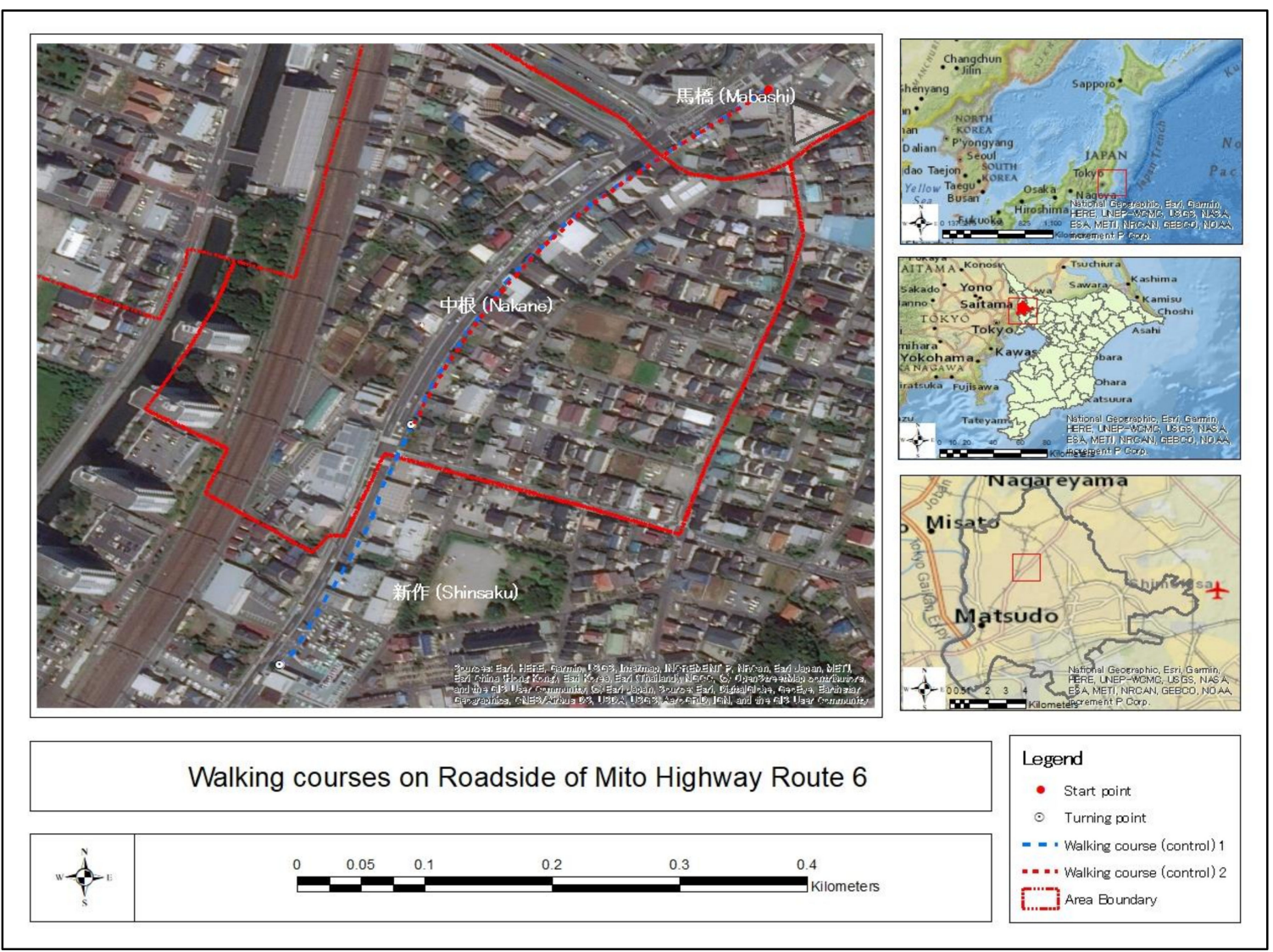

Figure 2. Control site map.

Table 1. Details regarding park (experimental site) and city (control site).

\begin{tabular}{|c|c|c|c|}
\hline Biophysical Aspects & Winter & Spring & Summer \\
\hline Route of walking course & $\begin{array}{c}\text { Experimental site: } \\
\text { Round trip of Village of } \\
\text { Green-Gathering Square } \\
\text { (walking course 1, 1.2 km) } \\
\text { City: } \\
\text { Roadside of Mito Highway } \\
\text { Route } 6 \text { (control walking } \\
\text { course } 1,1.2 \mathrm{~km} \text { ) }\end{array}$ & $\begin{array}{c}\text { Experimental site: } \\
\text { Round trip of Park center- } \\
\text { Nature Observation (walking } \\
\text { course 2,800 m) } \\
\text { City: } \\
\text { Roadside of Mito Highway } \\
\text { Route } 6 \text { (control walking } \\
\text { course } 2,800 \mathrm{~m} \text { ) }\end{array}$ & $\begin{array}{c}\text { Experimental site: } \\
\text { Round trip of Village of Green- } \\
\text { Gathering Square (walking } \\
\text { course 1, } 1.2 \mathrm{~km} \text { ) } \\
\text { City: } \\
\text { Roadside of Mito Highway } \\
\text { Route } 6 \text { (control walking } \\
\text { course } 1,1.2 \mathrm{~km} \text { ) }\end{array}$ \\
\hline Experimental Period & January 17-February 25, 2019 & $\begin{array}{l}\text { March 28-April } 3 \\
2019\end{array}$ & $\begin{array}{c}\text { May 30-June } 6 \\
2019\end{array}$ \\
\hline Land use & $\begin{array}{c}\text { Park: Secondary forest } \\
\text { White Oak (Quercus } \\
\text { myrsinifolia), Red Oak (Quercus } \\
\text { acuta), Zelkova (Zelkova } \\
\text { serrata), Muku tree } \\
\text { (Aphananthe aspera), Itajii } \\
\text { (Castanopsis sieboldii), Jolcham } \\
\text { Oak (Quercus serrata), Chino } \\
\text { bamboo (Pleioblastus chino) } \\
\text { City: Urban Area }\end{array}$ & $\begin{array}{c}\text { Park: Artificial planting } \\
\text { Yoshino Cherry (Prunus } \\
\text { yedoensis), Japanese cedar } \\
\text { (Cryptomeria japonica), Hinoki } \\
\text { cypress (Chamaecyparis obtuse), } \\
\text { Read Oak (Quercus acuta), } \\
\text { Jolcham oak (Quercus serrata), } \\
\text { Chino bamboo (Pleioblastus } \\
\text { chino) } \\
\text { City: Urban Area }\end{array}$ & $\begin{array}{c}\text { Park: Secondary forest } \\
\text { White Oak (Quercus } \\
\text { myrsinifolia), Red Oak (Quercus } \\
\text { acuta), Zelkova (Zelkova } \\
\text { serrata), Muku tree } \\
\text { (Aphananthe aspera), Itajii } \\
\text { (Castanopsis sieboldii), Jolcham } \\
\text { Oak (Quercus serrata), Chino } \\
\text { bamboo (Pleioblastus chino) } \\
\text { City: Urban Area }\end{array}$ \\
\hline $\begin{array}{c}\text { Temperature }\left({ }^{\circ} \mathrm{C}\right) \text { (mean } \\
\pm \mathrm{SD})\end{array}$ & $\begin{array}{l}\text { Park: } 12.2 \pm 1.4 \\
\text { City: } 13.4 \pm 1.7\end{array}$ & $\begin{array}{l}\text { Park: } 14.4 \pm 2.8 \\
\text { City: } 13.4 \pm 2.9\end{array}$ & $\begin{array}{l}\text { Park: } 26.7 \pm 2.6 \\
\text { City: } 26.7 \pm 1.5\end{array}$ \\
\hline $\begin{array}{l}\text { Relative humidity }(\%) \\
\quad(\text { mean } \pm \text { SD) }\end{array}$ & $\begin{array}{l}\text { Park: } 35.5 \pm 3.1 \\
\text { City: } 35.9 \pm 3.4\end{array}$ & $\begin{array}{l}\text { Park: } 45.4 \pm 18.1 \\
\text { City: } 40.6 \pm 14.2\end{array}$ & $\begin{array}{c}\text { Park: } 50.2 \pm 10 \\
\text { City: } 52 \pm 5.7\end{array}$ \\
\hline
\end{tabular}




\subsection{Participants}

The selection of participants was built up through a snowball sampling method as one of the best tools for finding potential participants dealing with the eligibility criteria. A total of 35 people became part of participants' recruitment via electronic mail and social networking services, and they provided information about study aims, experimental procedures, and designated experimental days. The eligibility criteria for participating in park therapy used the following criteria: (1) middle-aged and older adults aged between 40 and 80 and (2) not taking medication for cardiovascular disease and hypertension. In total, 12 participants living in several areas of Matsudo city (e.g., Tokiwadaira, Mabashi, and Koganehara) for each season were decided. As exhibited in previous physiological and psychological studies in park and forest environments, a sample size of 9-19 participants is enough to obtain significant results $[2,3,6,7,14,17,24,31,32]$. Therefore, 12 individuals in a set of experiment were sufficient to generate significant and relevant data. In total, four males and eight females (mean age, $70.2 \pm 4.4$ years) participated in the winter experiment, six males and six females (mean age, $66.4 \pm 10.5$ years) participated in the spring experiment, and five males and seven females (mean age, $65.75 \pm 10.1$ years) participated in the early summer experiment. After arriving at the sites, participants were briefed on the experiment procedures and informed consent in a waiting room. During the experimental period, alcohol, tobacco, caffeine, and food consumption was prohibited. The experimental procedures were in conformation with the regulations of the Ethics Committee of the Center for Environment, Health, and Field Sciences, Chiba University, Japan (Receipt code number: 18-06).

\subsection{Experimental Design}

Twelve participants were randomly classified into two groups (park and city group) in a day. Each group consisted of two to four participants. After arriving at each site, all participants were provided informed consent and guided walk orientations by staff, filled out questionnaires, measured blood pressure, and their heart rates began to be monitored. The participants then walked in the designated walking course in the park or city area for $15 \mathrm{~min}$ in winter and early summer, and $11 \mathrm{~min}$ in spring (Figure 3). Participants returned to the waiting room, filled out a set of questionnaires, got blood pressure checked, and stopped measuring heart rates. They had a lunch break for $30 \mathrm{~min}$. In the afternoon, the participants visited the reverse sites in order to terminate the effect of order (Table 2). Participants walked the designated course with views of Village of Green, Gathering Square, forest in winter and summer, and Yoshino-cherry and Sendabori pond in spring.

Table 2. Time schedules of walking experiment in winter, spring, and early summer. POMS: Profile of Mood States; STAI: State-Trait Anxiety Inventory; LIST: Landscape Image Sketching Technique.

\begin{tabular}{|c|c|c|}
\hline Time & Activity & Place \\
\hline 08:30 & Assembling at pickup point & $\begin{array}{l}\text { Tokiwadaira station building, } \\
\text { South gate }\end{array}$ \\
\hline 08:30-09:00 & Moving to park park/city area by car & - \\
\hline 09:00-09:20 & Guided orientation by staff & $\begin{array}{l}\text { Designated walking course at } \\
\text { park/city }\end{array}$ \\
\hline 09:20-09:40 & $\begin{array}{l}\text { Initial measurement of blood pressure and heart rate, } \\
\text { evaluation of POMS, STAI }\end{array}$ & Waiting room \\
\hline 09:40-10:00 & $\begin{array}{l}\text { Walking experiment with continuous heart rate } \\
\text { measurement }\end{array}$ & $\begin{array}{l}\text { Designated walking course at } \\
\text { park/city }\end{array}$ \\
\hline $10.00-10: 20$ & $\begin{array}{l}\text { Afterward measurement of blood pressure, evaluation of } \\
\text { POMS, STAI, LIST (only park group), termination of heart } \\
\text { rate measurement }\end{array}$ & Waiting room \\
\hline $11: 20-12: 00$ & Moving to the reverse sites by car & - \\
\hline $12: 00-12: 30$ & Having a lunch break & Waiting room \\
\hline
\end{tabular}


Table 2. Cont.

\begin{tabular}{ccc}
\hline Time & Activity & Place \\
\hline 12:30-12:50 & $\begin{array}{c}\text { Initial measurement of blood pressure and heart rate, } \\
\text { evaluation of POMS, STAI }\end{array}$ & Waiting room \\
& $\begin{array}{c}\text { Walking experiment with continuous heart rate } \\
\text { measurement }\end{array}$ & $\begin{array}{c}\text { Designated walking course at } \\
\text { park/city }\end{array}$ \\
& $\begin{array}{c}\text { Afterward measurement of blood pressure, evaluation of } \\
\text { POMS, STAI, LIST (only park group), termination of heart } \\
\text { rate measurement }\end{array}$ & Waiting room \\
\hline
\end{tabular}

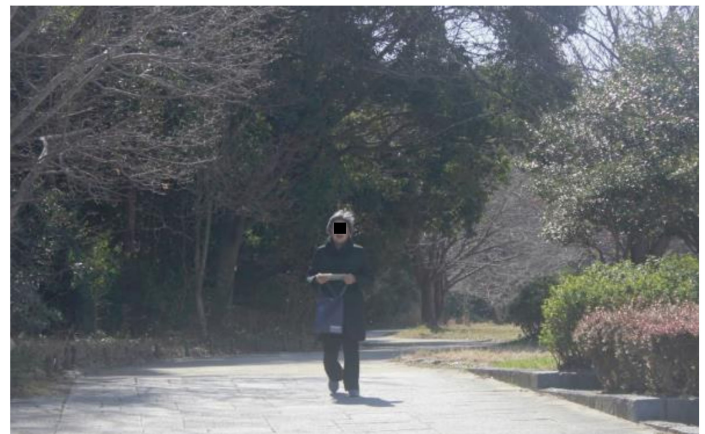

(a)

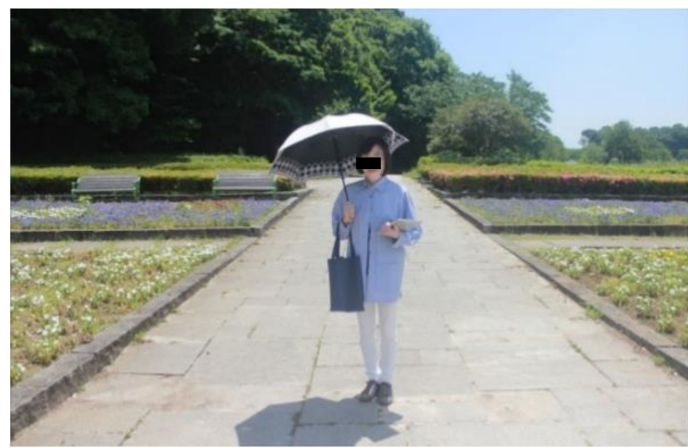

(c)

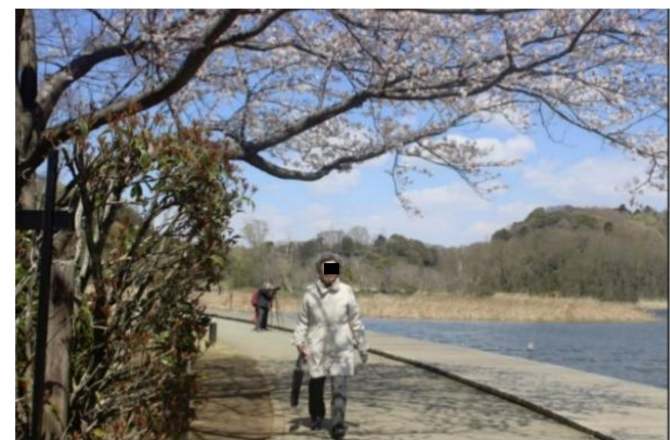

(b)

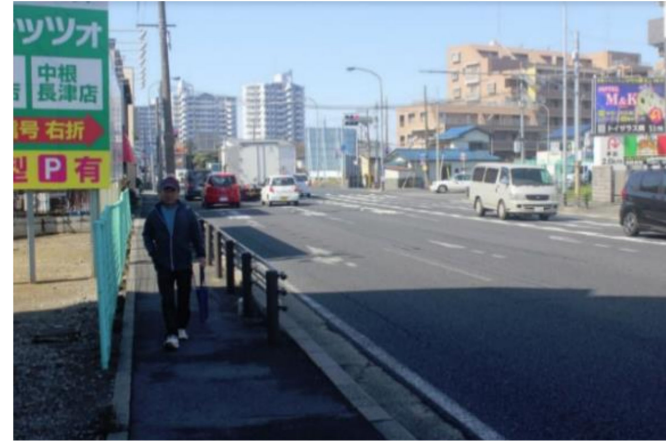

(d)

Figure 3. Walking course scenes in: (a) urban park in winter; (b) urban park in spring; (c) urban park in early summer; and (d) city area.

\subsection{Physiological and Psychological Measures}

Heart rate and blood pressure were measured as physiological parameters during the walking experiment. Heart rate was measured continuously using a heart rate sensor (MyBeat WHS-3, Union Tool, Tokyo, Japan). The average heart rate values during the walking period were used in the analysis. Systolic and diastolic blood pressure was measured by an oscillometric method using a digital automatic sphygmomanometer pre- and post-experiment (Omron HEM-1021, Omron Corp., Kyoto, Japan). The mean of two measurements was used in the analysis.

Two psychological parameters, namely the Profile of Mood States 2 (POMS) Japanese version and the new State-Trait Anxiety Inventory (STAI) Japanese version, were conveyed pre- and post-experiment. A POMS 2 is a reliable and valid measure of psychological response containing 35 questions complying six mood states: "anger-hostility" (A-H), "confusion-bewilderment" (C-B), "depression-dejection" (D-D), "fatigue-inertia" (F-I), tension-anxiety" (T-A), and "vigor-activity" (V-A). A five-point Likert scale, ranging from 0 (not at all) to 4 (extremely), was used for each item to evaluate subjects' mood states. The total mood disturbance (TMD) score was calculated as $[(\mathrm{A}-\mathrm{H})+(\mathrm{C}-\mathrm{B})+(\mathrm{D}-\mathrm{D})+(\mathrm{F}-\mathrm{I})$ $+(\mathrm{T}-\mathrm{A})-(\mathrm{V}-\mathrm{A})]$ [33-35]. A new STAI Japanese version was jointly researched in consideration of cultural factors and presented its consistency reliability [36,37]. The state anxiety part of STAI was 
used to measure the current state of anxiety which contains 20 questions. A four-point Likert scale, ranging from 1 (not at all) to 4 (very much so), was used to evaluate participants' state anxiety.

\subsection{Landscape Image Sketching Technique (LIST)}

Landscape Image Sketching Technique (LIST) is an approach that holistically analyzes environmental meaning, consisting of brief sketches of various landscapes, keywords referring to the landscape, and short verbal descriptions of landscapes by respondents $[26,27]$. The most distinct aspect of LIST is the analysis of visual data of scenic sketches. Sketches are unique representations of individual's landscape imageries [26-29]. In this study, this method could represent participants' view after walking towards spatial experienced the urban park environment and linguistic value orientation. Ueda et al. also emphasized that the three phases have four Fuukei (a Japanese word meaning landscape perception) conditions: (1) identification of landscape elements (through spatial view and linguistic knowledge); (2) structure of person-environment relationship (as self-orientation); and (3) the meaning (intersubjective values) of place according to how one's intentions are interpreted. Thus, park therapy images are central in the square model as they are comprised of every element (Figure 4) [27]. The landscape image survey (which consists of keywords, text, brief sketch of park therapy) was conducted after the walking experiment in the urban park to investigate the spatial conditions of park therapy.

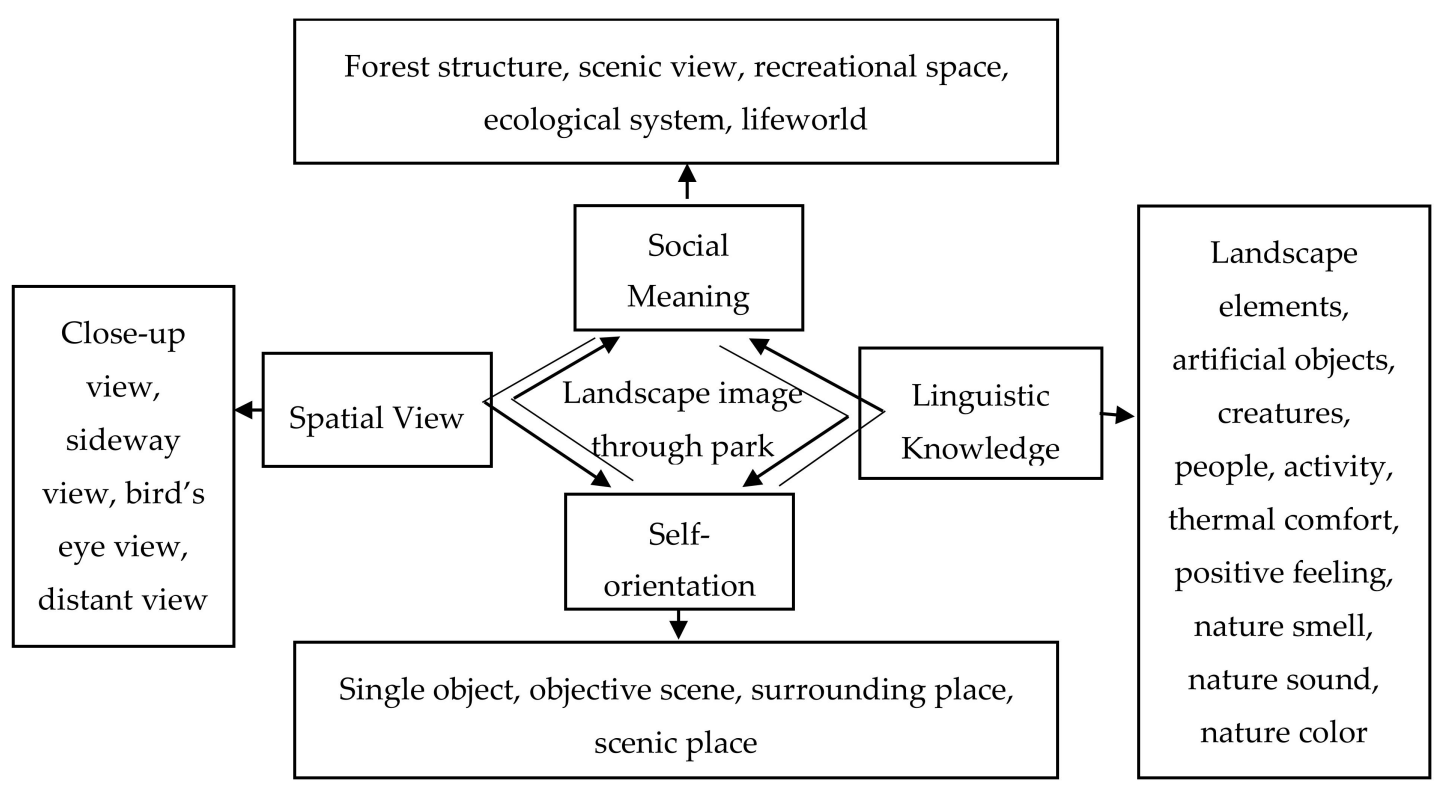

Figure 4. Diagram of landscape image through park walking. (Adapted from "Landscape image sketches of forests in Japan and Russia," by H. Ueda, T. Nakajima, N. Takayama, E. Petrova, H. Matsushima, K. Furuya, and Y. Aoki, 2012, Forest Policy and Economics, 19, 20-30. Copyright 2012 by H. Ueda).

\subsubsection{Keywords and Text of Forest}

In the landscape image survey, participants were asked to imagine park therapy images that they had experienced and then use words related to park therapy that could explain the situation within park therapy. The first step of LIST method showed the retrieval process of landscape cognition.

\subsubsection{Brief Sketch of Park}

The same participants were asked to draw a brief sketch of their landscape image. The second step of LIST aimed to complement incomplete verbal data from keywords and explanations regarding walking in the park. These following questions were asked to the middle-aged and older adults: 
- What imagery comes to mind when you hear the words "park therapy"? Regarding your own imagined "park therapy" please answer the following three questions.

- Please fill in the blanks with a few keywords about your free association "park therapy."

- Please explain the situation of your park therapy image using a few sentences (not more than 100 words).

- Please draw a brief sketch of your park therapy image (with keywords if necessary).

\subsection{Analysis Methods}

\subsubsection{Physiological-Psychological Measures Analyses}

Heart rate data were analyzed by averaging the number of times the heartbeats in the space of a minute at each site. Blood pressure data were divided into pre- and post- walking data in each site. A paired t-test was employed to compare mean differences of physiological measures between the two environments and pre- and post-walking in the urban park. The Wilcoxon signed-rank test was employed to assess whether their psychological measures mean ranks differ between the two environments and pre- and post-walking in the urban park. The Kruskal-Wallis test was employed to determine the difference of participants' characteristics during park therapy in all seasons.

In a comparative analysis, the heart rate, blood pressure, total mood disturbance, and state anxiety outcomes were compared with those of our prior study that investigated physiological and psychological effects of viewing an urban park for 11-15 min [24]. The number of participants who exhibited positive and negative responses in the current and prior results were counted for comparative analysis [9]. A positive response was implied by an alleviation in heart rate, blood pressure, TMD, state anxiety, and a negative response as the reverse. The chi-squared test was employed to compare the difference in the proportion of positive and negative responses between the current and prior studies.

\subsubsection{Landscape Image Analysis}

An analysis of visual and verbal data was implemented onto four Fuukei conditions (landscape image aspects): (1) identification of landscape elements (through linguistic knowledge and spatial view); (2) structure of person-environment relationship (through self-orientation); and (3) meaning of place (through social meaning) [27]. Each landscape image sketch was classified into landscape image aspects using a checklist method. The presence of the variables in the landscape image sketches was defined as ' 1 ', while ' 0 ' indicated the absence of the variables in the landscape image sketches [28]. The chi-square test was applied to compare the variables of verbal and visual data of landscape image. Spearman's rho correlation was applied to analyze the correlation between park therapy images and physiological-psychological measures.

All statistical analyses were applied using SPSS 26.0 (IBM Corp., Armonk, NY, USA). Quantitative content analysis was conducted using KH Coder 3 to quantify the highest degree of centrality. The explanatory verbal data of landscape images was examined by automatically extracting frequent words from data, statistically analyzing them to obtain entire landscape images, and exploring features of data while avoiding researcher prejudice [38].

\section{Results}

\subsection{Participant Sociodemographic, Socioeconomic, and Shinrin-Yoku Information}

The information regarding participant socio-demography, socio-economy, and shinrin-yoku is shown in Table 3. Based on the Kruskal-Wallis test, the participants' characteristics during park therapy were not significantly different in all seasons. In this study, the mean age of the middle-aged and older adults was $70.2 \pm 4.4$ in winter, $66.4 \pm 10.5$ in spring, and $66.8 \pm 10.1$ in summer. The proportion of male and female participants was similar in all seasons (33.3\% of males and $66.7 \%$ of females; $50 \%$ of males and $50 \%$ females; $41.7 \%$ males, and $58.3 \%$ females, respectively). In terms of employment 
status, $75 \%$ of participants were unemployed while $25 \%$ were employed. Regarding their educational background, $44.4 \%$ of participants held vocational education, $30.6 \%$ graduated from senior high school, $22.2 \%$ held a university degree, and $2.7 \%$ only completed from junior high school. Regarding monthly income, $47.2 \%$ of participants had less than JPY 150,000, 30.6\% had between JPY 150,000-200,000, $11.1 \%$ had more than JPY 250,000, and 8.3\% had JPY 200,000-250,000. With regard to health, $94.4 \%$ participants did not smoke, $63.9 \%$ slept less than $7 \mathrm{~h}$, and $52.8 \%$ did not consume alcohol. Participants performed sports or exercise activity seven times and shinrin-yoku five times in a month. About $55.5 \%$ of the participants felt sufficient in social attachment to their environment, marked by bi-monthly community involvement.

Table 3. Participant Information.

\begin{tabular}{|c|c|c|c|c|}
\hline Parameter & Winter $(N=12)$ & Spring $(N=12)$ & Summer $(N=12)$ & $P$-Value \\
\hline Age (years) & $70.2 \pm 4.4$ & $66.4 \pm 10.5$ & $66.8 \pm 10.1$ & 0.791 \\
\hline Gender & & & & 0.635 \\
\hline Male & $33.3 \%$ & $50 \%$ & $41.7 \%$ & \\
\hline Female & $66.7 \%$ & $50 \%$ & $58.3 \%$ & \\
\hline Employment status & & & & 0.535 \\
\hline No & $83.3 \%$ & $66.7 \%$ & $75 \%$ & \\
\hline Yes & $16.67 \%$ & $33.3 \%$ & $25 \%$ & \\
\hline Educational background & & & & 0.534 \\
\hline Junior high school & $8.3 \%$ & - & - & \\
\hline Senior high school & $33.3 \%$ & $25 \%$ & $33.3 \%$ & \\
\hline University & $16.7 \%$ & $16.7 \%$ & $33.3 \%$ & \\
\hline Other (vocational education) & $41.7 \%$ & $58.3 \%$ & $33.3 \%$ & \\
\hline Income (JPY/month) & & & & 0.882 \\
\hline Less than JPY 150,000 & $41.7 \%$ & $41.7 \%$ & $58.3 \%$ & \\
\hline JPY 150,000-200,000 & $41.7 \%$ & $25 \%$ & $25 \%$ & \\
\hline JPY 200,000-250,000 & $8.3 \%$ & $16.7 \%$ & - & \\
\hline More than JPY 250,000 & $8.3 \%$ & $16.7 \%$ & $16.7 \%$ & \\
\hline Smoking behavior & & & & 0.368 \\
\hline No & $100 \%$ & $91.7 \%$ & $91.7 \%$ & \\
\hline Yes & - & $8.3 \%$ & $8.3 \%$ & \\
\hline Alcohol use & & & & 0.897 \\
\hline No & $50 \%$ & $58.3 \%$ & $50 \%$ & \\
\hline Yes & $50 \%$ & $41.7 \%$ & $50 \%$ & \\
\hline Sleeping time (hours) & & & & 0.893 \\
\hline Less than $7 \mathrm{~h}$ & $58.3 \%$ & $66.7 \%$ & $66.7 \%$ & \\
\hline $7-9 \mathrm{~h}$ & $41.7 \%$ & $33.3 \%$ & $33.3 \%$ & \\
\hline Sport activity (times/month) & $7.2 \pm 6.6$ & $5 \pm 5.5$ & $7.6 \pm 9.3$ & 0.658 \\
\hline Shinrin-yoku (times) & $2.6 \pm 3.8$ & $6.6 \pm 5$ & $5.6 \pm 8.5$ & 0.741 \\
\hline Social attachment & & & & 0.504 \\
\hline Sometimes & $50 \%$ & $66.7 \%$ & $50 \%$ & \\
\hline Quite often & $41.7 \%$ & $25 \%$ & $16.7 \%$ & \\
\hline Often & $8.3 \%$ & $8.3 \%$ & $33.3 \%$ & \\
\hline $\begin{array}{l}\text { Participation in community } \\
\text { (times/month) }\end{array}$ & $2.3 \pm 4.4$ & $1.6 \pm 1.9$ & $1.6 \pm 2.8$ & 0.994 \\
\hline
\end{tabular}

\subsection{Reliability Analysis of Physiological and Psychological Parameters}

The internal consistency (Cronbach's alphas) of physiological and psychological parameters among 12 participants in winter, spring, and summer is provided in Table 4 . The overall parameters obtained very good internal consistency (0.817-0.989). The results show that heart rate and blood pressure as physiological parameters had excellent internal consistency (more than 0.9), while POMS and STAI scores as psychological parameters had good internal consistency (more than 0.8 ). The alpha reliability of heart rate in winter, spring, and summer was $0.980,0.982$, and 0.989 , respectively. For blood pressure, it was $0.936,0.908$, and 0.849 , respectively. While the alpha reliability of the POMS score in winter, spring, and summer was $0.901,0.817$, and 0.887, respectively. For the STAI score in winter, spring, and summer, it was $0.882,0.858$, and 0.930 , respectively. 
Table 4. Verification of internal consistency of physiological and psychological parameters.

\begin{tabular}{cccc}
\hline \multirow{2}{*}{ Parameter } & \multicolumn{3}{c}{ Cronbach's $\alpha$} \\
\cline { 2 - 4 } & Winter & Spring & Summer \\
\hline Heart rate & 0.980 & 0.982 & 0.989 \\
Blood pressure & 0.936 & 0.908 & 0.849 \\
POMS & 0.901 & 0.817 & 0.887 \\
STAI & 0.882 & 0.858 & 0.930 \\
\hline
\end{tabular}

\subsection{Physiological Effects}

Walking in the urban park was found to result in lower heart rate and blood pressure than walking in the city. The significant health effect of walking in the urban park on middle-aged and older adults was varied by season. In all seasons, mean heart rates while walking in the urban park were lower than in the city (winter: $p=0.000$; spring: $p=0.023$; early summer: $p=0.000$; Table 5). Figure 5 depicts overall mean heart rates during walk in urban park and city area in winter, spring, and early summer. Mean systolic and diastolic blood pressure in spring were significantly lower after walking in the urban park as compared to the city $(p=0.000 ; p=0.002$; Figure 6$)$. There were no significant differences in blood pressures in two environments in winter and early summer.

Table 5. Mean heart rate during and blood pressure post-walking in the urban park and city area in winter, spring, and early summer.

\begin{tabular}{|c|c|c|c|}
\hline \multirow{2}{*}{$\begin{array}{l}\text { Physiological } \\
\text { Parameters }\end{array}$} & Park & City & \multirow{2}{*}{$P$-Value } \\
\hline & Mean \pm SD & Mean \pm SD & \\
\hline \multicolumn{4}{|l|}{ Heart rate (bpm) } \\
\hline Winter & $100.4 \pm 1.6$ & $104.4 \pm 2.0$ & $0.000^{* * *}$ \\
\hline Spring & $97.6 \pm 2.1$ & $99.6 \pm 2.1$ & 0.023 * \\
\hline Early summer & $89.7 \pm 1.5$ & $92.7 \pm 1.4$ & $0.000^{* * *}$ \\
\hline \multicolumn{4}{|c|}{$\begin{array}{l}\text { Systolic Blood pressure } \\
(\mathrm{mmHg})\end{array}$} \\
\hline Winter & $127.6 \pm 20.5$ & $130.5 \pm 21.0$ & 0.319 \\
\hline Spring & $126.3 \pm 17.0$ & $147.3 \pm 13.3$ & $0.000 * * *$ \\
\hline Early summer & $124.7 \pm 21.4$ & $129.3 \pm 20.4$ & 0.25 \\
\hline \multicolumn{4}{|l|}{$\begin{array}{l}\text { Diastolic Blood } \\
\text { pressure (mmHg) }\end{array}$} \\
\hline Winter & $72.2 \pm 15.9$ & $74.2 \pm 15.2$ & 0.277 \\
\hline Spring & $76.0 \pm 11.9$ & $87.5 \pm 8.4$ & $0.002 * *$ \\
\hline Early summer & $70.3 \pm 10.0$ & $73.0 \pm 9.8$ & 0.242 \\
\hline
\end{tabular}

Note. ${ }^{*} p<0.05,{ }^{* *} p<0.01,{ }^{* * *} p<0.001$. 


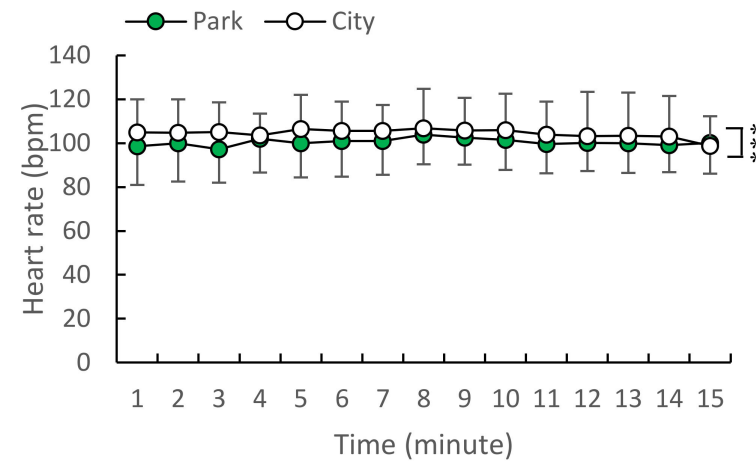

(a)

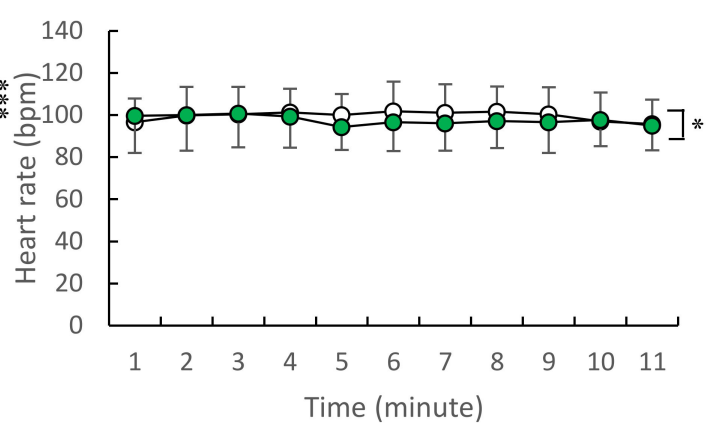

(b)

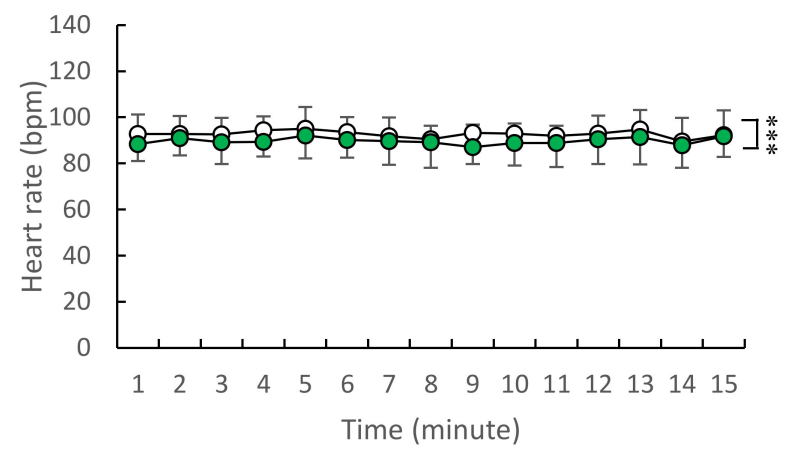

(c)

Figure 5. One min average heart rate during walking in the urban park in (a) winter, (b) spring, and (c) early summer. $N=12$, mean \pm standard deviation. ${ }^{*} p<0.05$, ${ }^{* * *} p<0.001$, analyzed by the paired $t$-test (one-sided).

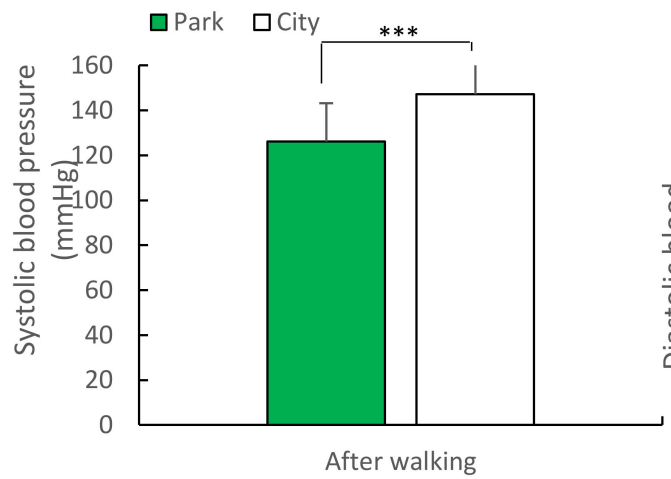

(a)

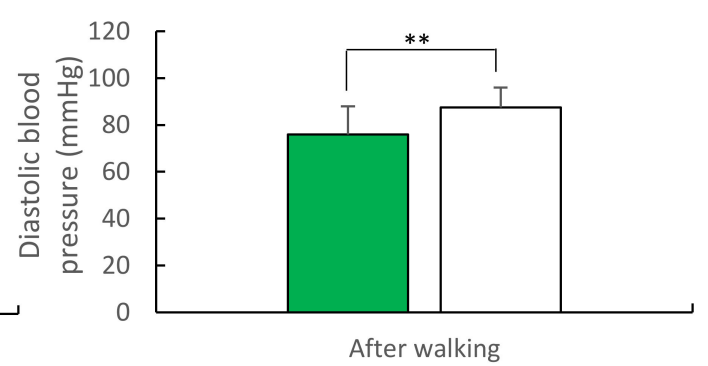

(b)

Figure 6. Average blood pressure after walking in the urban park in spring: (a) systolic blood pressure; (b) diastolic blood pressure. $N=12$, mean \pm standard deviation. ${ }^{* *} p<0.01$, ${ }^{* * *} p<0.001$, analyzed by the paired $t$-test (one-sided). 
The physiological outcomes of the current study were compared with our prior study's outcomes in which participants viewed urban parks [24]. The proportions of participants who exhibited positive and negative responses in urban parks are shown in Table 6. In prior results [20], 83.3\% of participants exhibited the highest proportion of positive responses in systolic and diastolic blood pressure after viewing urban parks in spring. This was significantly lower than those post-walking $(91.7 \%)$ in the current study $(p=0.020)$. The proportion of participants exhibiting positive response in systolic (50\% and $75 \%)$ and diastolic blood pressure (66.7\% and $75 \%$ ) was almost equal between post-early summer walking and viewing in urban parks, and there was no significant difference. In current results, $66.7 \%$ of the participants exhibited higher positive responses in heart rate during spring and early summer walking in urban parks than those during viewing $(16.7 \%)$ in the prior study. Both proportions of participants in heart rates between two studies in spring and early summer found no significant difference.

Table 6. Proportions of participants who exhibited positive and negative responses in heart rate during and blood pressure post-walking and viewing in urban parks.

\begin{tabular}{cccccccc}
\hline \multirow{2}{*}{ Season } & \multirow{2}{*}{ Activity } & \multicolumn{2}{c}{ Heart Rate } & \multicolumn{2}{c}{ Systolic Blood Pressure } & \multicolumn{2}{c}{$\begin{array}{c}\text { Diastolic Blood } \\
\text { Pressure }\end{array}$} \\
\cline { 3 - 8 } & & $\begin{array}{c}\text { Positive } \\
\text { Response }\end{array}$ & $\begin{array}{c}\text { Negative } \\
\text { Response }\end{array}$ & $\begin{array}{c}\text { Positive } \\
\text { Response }\end{array}$ & $\begin{array}{c}\text { Negative } \\
\text { Response }\end{array}$ & $\begin{array}{c}\text { Positive } \\
\text { Response }\end{array}$ & $\begin{array}{c}\text { Negative } \\
\text { Response }\end{array}$ \\
\hline Winter & Walking & $8(66.7 \%)$ & $4(33.3 \%)$ & $7(58.3 \%)$ & $5(41.7 \%)$ & $8(66.7 \%)$ & $4(33.3 \%)$ \\
$(N=12)$ & Viewing & - & - & - & - & - & - \\
\hline Spring & Walking & $8(66.7 \%)$ & $4(33.3 \%)$ & $11(91.7 \%)$ & $1(8.3 \%)$ & $11(91.7 \%)$ & $1(8.3 \%)$ \\
$(N=12)$ & Viewing & $2(16.7 \%)$ & $10(83.3 \%)$ & $10(83.3 \%)$ & $2(16.7 \%)$ & $10(83.3 \%)$ & $2(16.7 \%)$ \\
\hline Chi-squared test & & \multicolumn{2}{c}{$1.200(p=0.273)$} & $5.455(p=0.020)$ & $5.455(p=0.020)$ \\
\hline Early summer & Walking & $8(66.7 \%)$ & $4(33.3 \%)$ & $6(50 \%)$ & $6(50 \%)$ & $8(66.7 \%)$ & $4(33.3 \%)$ \\
$(N=12)$ & Viewing & $2(16.7 \%)$ & $10(83.3 \%)$ & $9(75 \%)$ & $3(25 \%)$ & $9(75 \%)$ & $3(25 \%)$ \\
\hline Chi-squared test & & \multicolumn{2}{c}{$1.200(p=0.273)$} & $0.444(p=0.505)$ & $2.000(p=0.157)$ \\
\hline
\end{tabular}

\subsection{Psychological Effects}

Compared to walking in a city, brief walking in the urban park led to fewer negative moods and state anxiety, as well as higher positive moods. In winter, there was a significant reduction of negative moods in the POMS analysis, with negative subscale scores ranging from "confusion-bewilderment" $(p=0.029)$ and "depression-dejection" $(p=0.042)$. Moreover, TMD significantly lowered after park therapy ( $p=0.023$; Figure 7). The mean values of negative moods "fatigue-inertia" proved that TMD decreased, whereas "vigor-activity" increased in post-walking compared with pre-walking in the urban park (F-I: $p=0.012$; TMD: $p=0.003$; V-A: $p=0.042$; Figure 8). In spring, "depression-dejection" $(p=0.036)$, "vigor-activity" ( $p=0.037)$, and TMD $(p=0.008)$ were significantly lower after park therapy. In early summer, "anger-hostility" ( $p=0.039)$, "confusion-bewilderment" $(p=0.021)$, "fatigue-inertia" $(p=0.007)$, and "tension-anxiety" ( $p=0.035)$ were significantly lower following park therapy (Table 7). The significant difference in mood change between pre- and post-walking in the urban park was not detected in spring and early summer. STAI analysis demonstrated significant decreases in state anxiety after seasonally walking in the urban park compared with the city area $(p=0.0125 ; p=0.028 ; p=0.027$, respectively; Figure 9). The mean values of state anxiety declined in post-walking compared with pre-walking in the urban park during winter $(p=0.008$; Figure 10). 

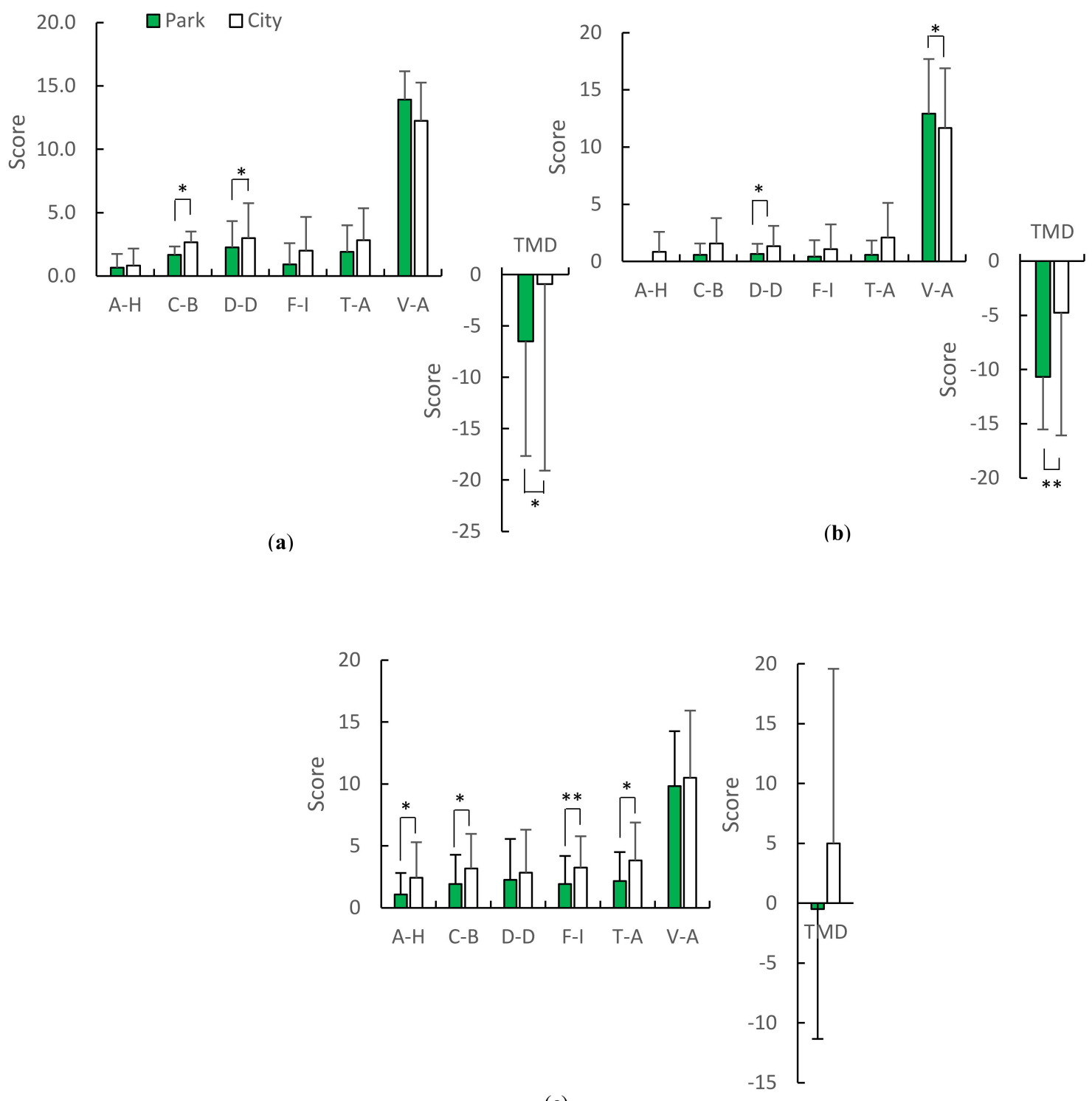

(c)

Figure 7. Comparison of POMS scores after walking between the two environments in: (a) winter; (b) spring; (c) early summer. T-A, tension-anxiety; D-D, depression-dejection; A-H, anger-hostility; F-I, fatigue-inertia; C-B, confusion-bewilderment; V-A, vigor-activity; TMD: total mood disturbance. $N=12$, mean \pm standard deviation. ${ }^{*} p<0.05$, ${ }^{* *} p<0.01$, analyzed by the Wilcoxon signed-rank test (one-sided). 

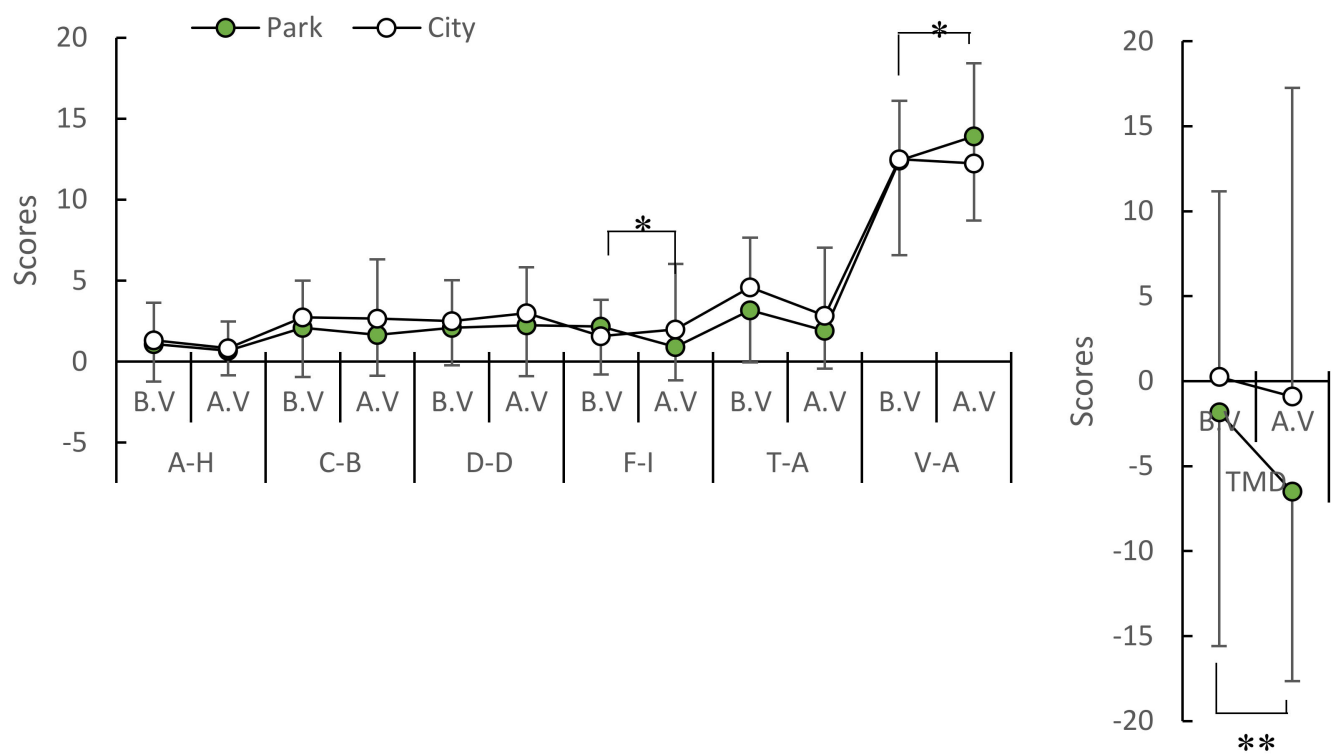

Figure 8. Comparison of POMS scores pre- and post-walking in the urban park in the winter. A-H: anger-hostility; C-B: confusion-bewilderment; D-D: depression-dejection; F-I: fatigue-inertia; T-A: tension-anxiety; V-A: vigor-activity; TMD: total mood disturbance. $N=12$, mean \pm standard deviation. ${ }^{*} p<0.05,{ }^{* *} p<0.01$, analyzed by the Wilcoxon signed-rank test (one-sided).

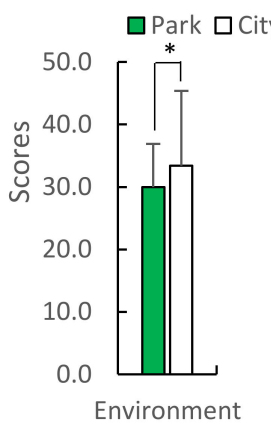

(a)

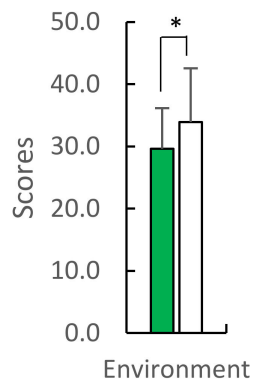

(b)

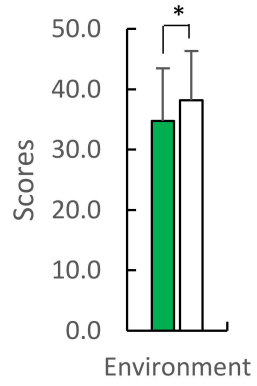

(c)

Figure 9. Comparison of STAI scores after walking between the two environments in: (a) winter; (b) spring; and (c) early summer. $N=12$, mean \pm standard deviation. ${ }^{*} p<0.05$, analyzed by the Wilcoxon signed-rank test (one-sided).

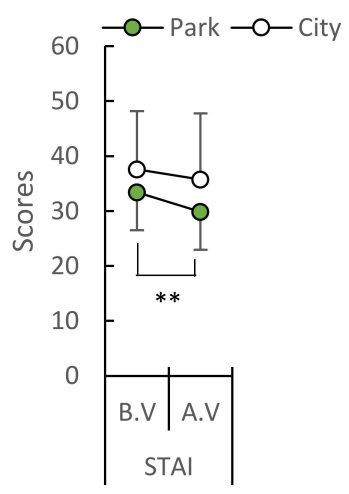

Figure 10. Comparison of STAI score pre- and post-walking in the urban park in winter. $N=12$, mean \pm standard deviation. ${ }^{* *} p<0.01$, analyzed by the Wilcoxon signed-rank test (one-sided). 
Table 7. Mean POMS and STAI scores for post-walking in the urban park and city area in winter, spring, and early summer.

\begin{tabular}{|c|c|c|c|}
\hline \multirow{2}{*}{ Psychological Parameters } & Park & City & \multirow{2}{*}{$P$-Value } \\
\hline & Mean \pm SD & Mean \pm SD & \\
\hline \multicolumn{4}{|l|}{ Mood State (POMS) } \\
\hline \multicolumn{4}{|l|}{ Winter } \\
\hline Anger-hostility (A-H) & $0.7 \pm 1.5$ & $0.8 \pm 1.6$ & 0.297 \\
\hline Confusion-bewilderment (C-B) & $1.7 \pm 2.5$ & $2.7 \pm 3.7$ & $0.029 *$ \\
\hline Depression-dejection (D-D) & $2.3 \pm 3.1$ & $3.0 \pm 2.8$ & 0.042 * \\
\hline Fatigue-inertia (F-I) & $0.9 \pm 2.1$ & $2.0 \pm 4.0$ & 0.051 \\
\hline Tension-anxiety (T-A) & $1.9 \pm 2.4$ & $2.8 \pm 4.2$ & 0.147 \\
\hline Vigor-activity (V-A) & $13.9 \pm 5.2$ & $12.3 \pm 6.2$ & 0.054 \\
\hline Total Mood Disturbance (TMD) & $-6.5 \pm 11.1$ & $-0.9 \pm 18.2$ & $0.023 *$ \\
\hline \multicolumn{4}{|l|}{ Spring } \\
\hline Anger-hostility (A-H) & $0.0 \pm 0.0$ & $0.8 \pm 1.7$ & 0.055 \\
\hline Confusion-bewilderment (C-B) & $0.6 \pm 1.0$ & $1.6 \pm 2.2$ & 0.053 \\
\hline Depression-dejection (D-D) & $0.7 \pm 0.9$ & $1.3 \pm 1.8$ & $0.036^{*}$ \\
\hline Fatigue-inertia (F-I) & $0.4 \pm 1.4$ & $1.1 \pm 2.2$ & 0.09 \\
\hline Tension-anxiety (T-A) & $0.6 \pm 1.2$ & $2.1 \pm 3.0$ & 0.084 \\
\hline Vigor-activity (V-A) & $12.9 \pm 4.8$ & $11.7 \pm 5.2$ & 0.037 * \\
\hline Total Mood Disturbance (TMD) & $-10.7 \pm 4.8$ & $-4.8 \pm 11.3$ & $0.008^{* *}$ \\
\hline \multicolumn{4}{|l|}{ Early summer } \\
\hline Anger-hostility $(\mathrm{A}-\mathrm{H})$ & $1.1 \pm 1.7$ & $2.4 \pm 2.9$ & 0.039 * \\
\hline Confusion-bewilderment (C-B) & $1.9 \pm 2.4$ & $3.2 \pm 2.8$ & $0.021 *$ \\
\hline Depression-dejection (D-D) & $2.3 \pm 3.3$ & $2.8 \pm 3.5$ & 0.274 \\
\hline Fatigue-inertia (F-I) & $1.9 \pm 2.3$ & $3.3 \pm 2.5$ & $0.007^{* *}$ \\
\hline Tension-anxiety (T-A) & $2.2 \pm 2.3$ & $3.8 \pm 3.0$ & 0.035 * \\
\hline Vigor-activity (V-A) & $9.8 \pm 4.4$ & $10.5 \pm 5.4$ & 0.311 \\
\hline Total Mood Disturbance (TMD) & $-0.5 \pm 10.8$ & $5.0 \pm 14.6$ & 0.054 \\
\hline \multicolumn{4}{|l|}{ State Anxiety (STAI) } \\
\hline Winter & $29.8 \pm 6.9$ & $35.8 \pm 12.0$ & $0.013 *$ \\
\hline Spring & $29.6 \pm 6.6$ & $33.9 \pm 8.6$ & 0.028 * \\
\hline Early summer & $34.8 \pm 8.7$ & $38.2 \pm 8.2$ & 0.027 * \\
\hline
\end{tabular}

Note. ${ }^{*} p<0.05,{ }^{* *} p<0.01$.

The psychological outcomes of the current study were compared with those of our prior study in which participants merely view urban parks [24]. The proportions of participants who exhibited positive and negative responses in urban parks are shown in Table 8 . In our prior results [20], 91.7\% of the participants exhibited the highest positive responses in state anxiety in post-early summer viewing of urban parks. State anxiety was lower than that post- viewing (75\%) and a significant difference was not found. In the current results, $91.7 \%$ of the participants exhibited the highest positive responses in total mood disturbance during post-spring walking in urban parks. Total mood disturbance was higher than that post-viewing $(66.7 \%)$ in the prior study; a significant difference was not found. The proportion of participants exhibiting positive response in state anxiety was almost equal between post-spring walking and viewing in urban parks $(66.7 \%, 75 \%)$. Total mood disturbance was similar between post-early summer walking and viewing in urban parks $(66.7 \%)$, and no significant difference was found. 
Table 8. Proportions of participants who exhibited positive and negative responses in total mood disturbance and state anxiety post-walking and viewing in urban parks.

\begin{tabular}{cccccc}
\hline \multirow{2}{*}{ Season } & \multirow{2}{*}{ Activity } & \multicolumn{2}{c}{ Total Mood Disturbance } & \multicolumn{2}{c}{ State Anxiety } \\
\cline { 3 - 6 } & & $\begin{array}{c}\text { Positive } \\
\text { Response }\end{array}$ & $\begin{array}{c}\text { Negative } \\
\text { Response }\end{array}$ & $\begin{array}{c}\text { Positive } \\
\text { Response }\end{array}$ & $\begin{array}{c}\text { Negative } \\
\text { Response }\end{array}$ \\
\hline Winter & Walking & $10(83.3 \%)$ & $2(16.7 \%)$ & $10(83.3 \%)$ & $2(16.7 \%)$ \\
$(N=12)$ & Viewing & - & - & - & - \\
\hline Spring & Walking & $11(91.7 \%)$ & $1(8.3 \%)$ & $8(66.7 \%)$ & $4(33.3 \%)$ \\
$(N=12)$ & Viewing & $8(66.7 \%)$ & $4(33.3 \%)$ & $9(75 \%)$ & $3(25 \%)$ \\
\hline Chi-Squared Tests & & $2.182(p=0.140)$ & $2.000(p=0.157)$ \\
\hline Early summer & Walking & $8(66.7 \%)$ & $4(33.3 \%)$ & $9(75 \%)$ & $3(25 \%)$ \\
$(N=12)$ & Viewing & $8(66.7 \%)$ & $4(33.3 \%)$ & $11(91.7 \%)$ & $1(8.3 \%)$ \\
\hline Chi-Squared Tests & & \multicolumn{2}{c}{$1.188(p=0.665)$} & \multicolumn{2}{c}{$0.364(p=0.546)$} \\
\hline
\end{tabular}

\subsection{Image of Park Therapy}

Park therapy-related landscape images showed prominent landscape elements such as "trees" ( $p$ $=0.004)$ in winter, "water" $(p=0.031)$ in spring, "activity" $(p=0.038)$ and "people" $(p=0.034)$ in spring, and "greenery" ( $p=0.008)$ and "lawn" $(p=0.038)$ in early summer. A therapeutic feeling was associated with "comfortable" ( $p=0.038)$ and "relaxed" $(p=0.015)$ in winter, as well as "broad" in early summer $(p=0.038)$. Self-orientation and social meaning were explored during spring, such as "surrounding place" $(p=0.045)$ and "recreational space" $(p=0.014)$ (Table 9). In the winter, park therapy images were characterized by deciduous trees that shed leaves. This represents comfortable and relaxed feelings when one walks through the park. In spring, park therapy images were characterized by surrounding places that expressed subjects' perspectives on the park, with trails or cherry blossom-viewing spots at the center and water as a background to describe subject's activities. In the summer, park therapy images were characterized by wide lawns and fresh greenery in the park. Figures 11-13 shows park therapy images in winter, spring, and early summer.
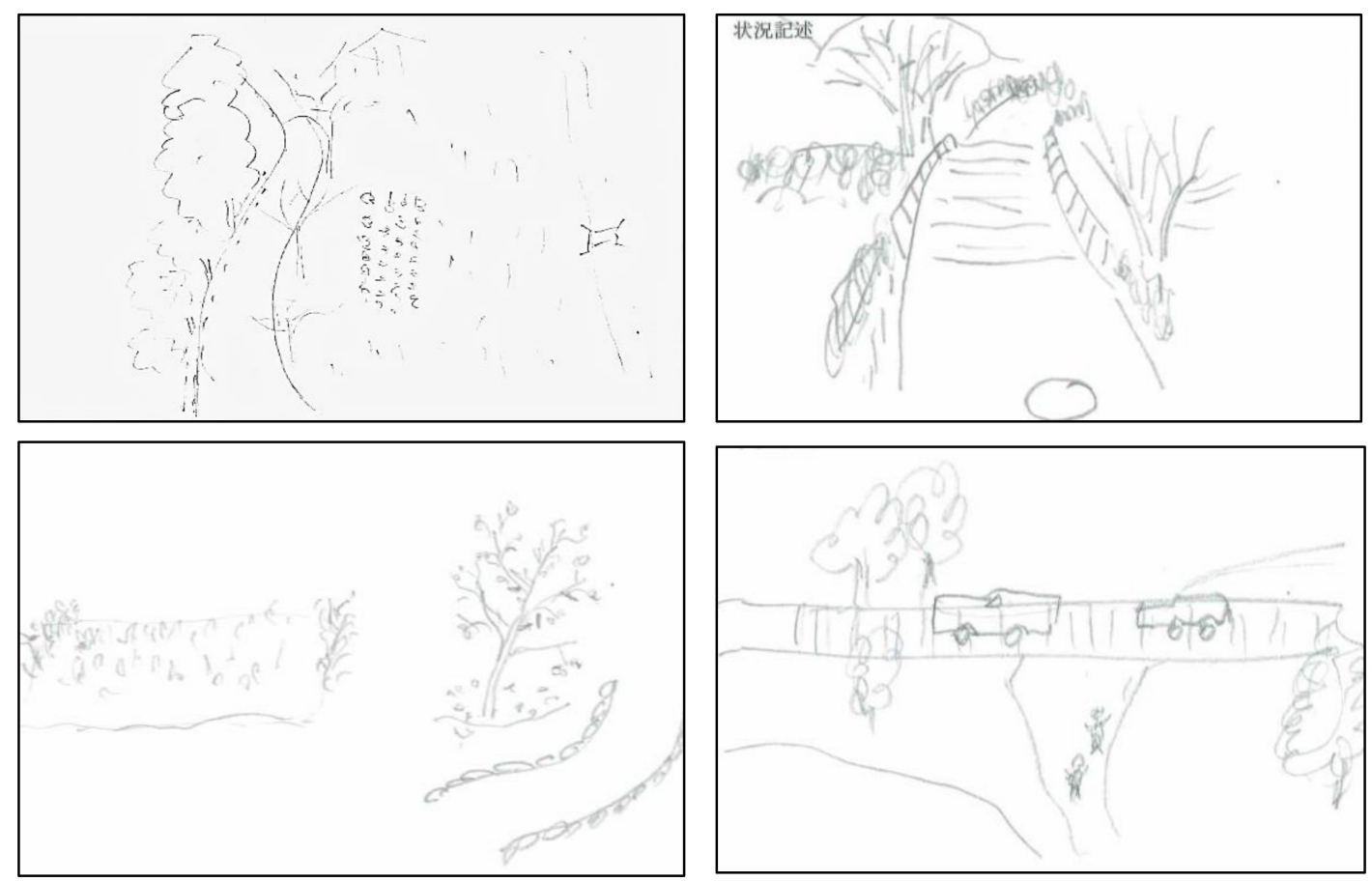

Figure 11. Park therapy sketches in winter. 

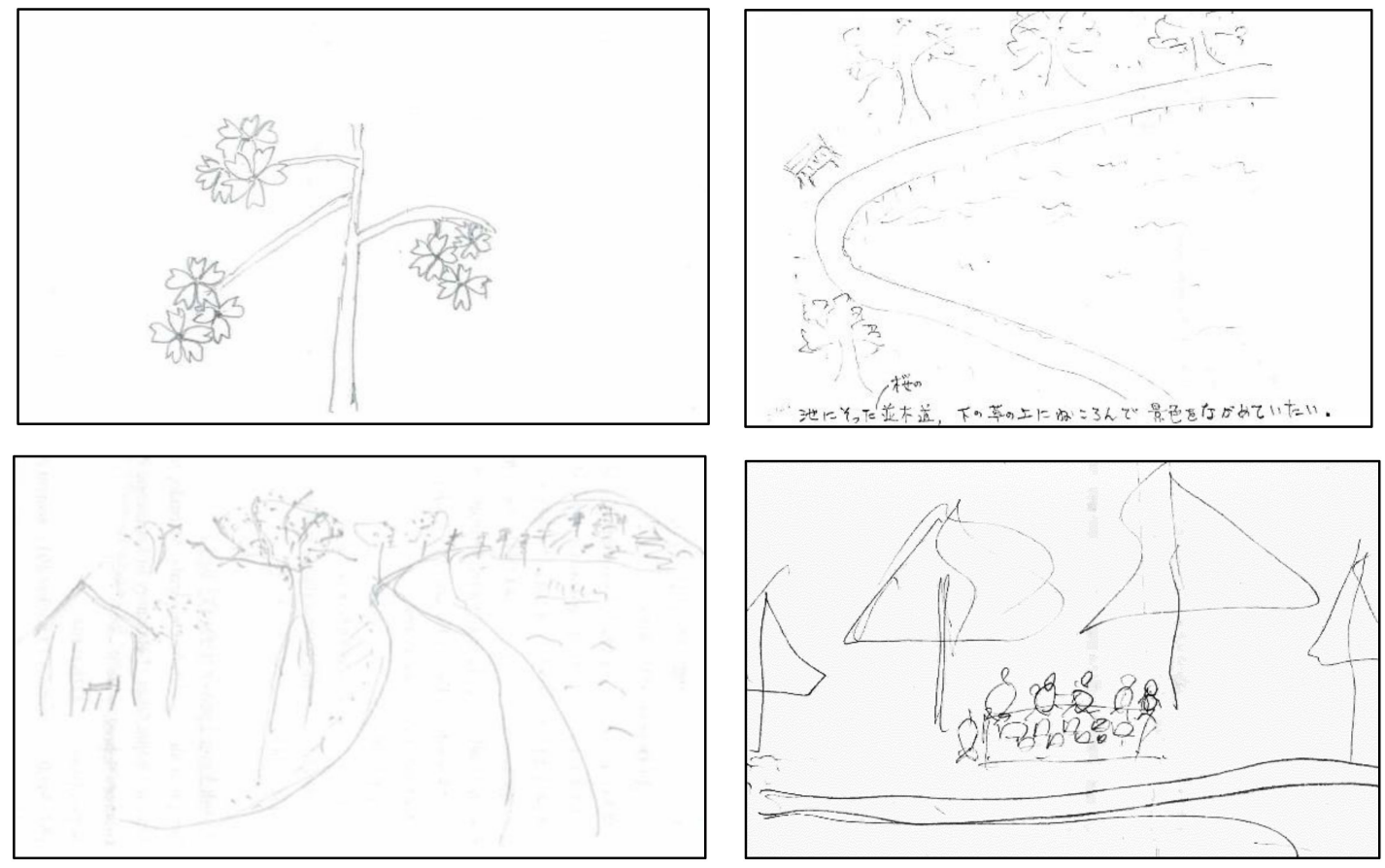

Figure 12. Park therapy sketches in spring.
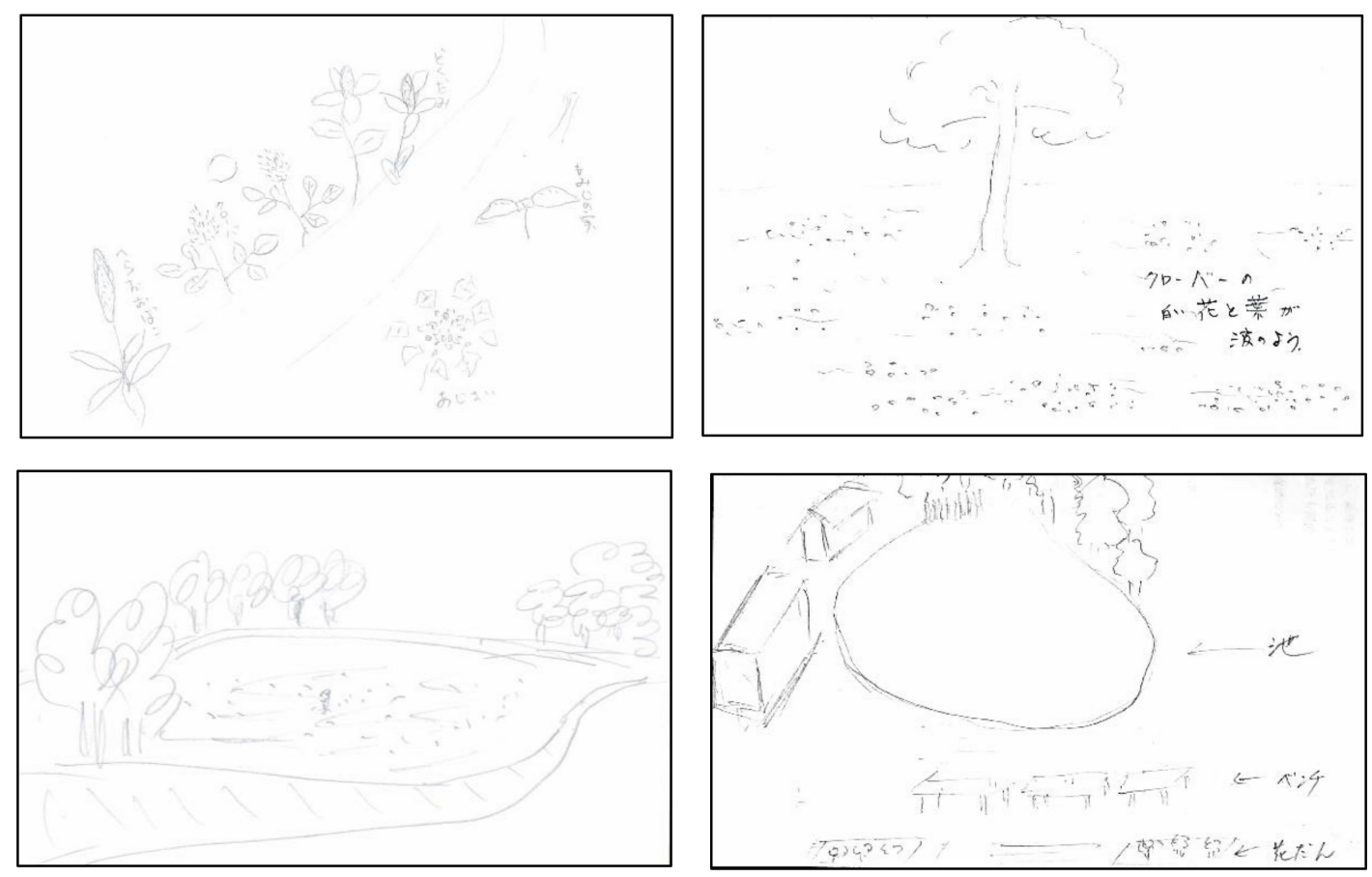

Figure 13. Park therapy sketches in summer.

This study also exhibited a correlation between park therapy images and physiological-psychological responses. One linguistic knowledge component correlated with physiological-psychological responses in winter, four linguistic knowledge components, each one spatial view and self-orientation components correlated with physiological-psychological responses in spring, and three linguistic knowledge and two spatial view components were correlated in early summer (Table 10). Green leaves and plants had correlations with increased vigor-activity in spring $(r=0.619)$. Creatures like "birds" as landscape elements during park therapy had correlations with decreased heart rates in winter. In spring, such 
landscape elements had correlations with decreased systolic blood pressure, increased vigor, decreased TMD, and state anxiety $(r=-0.607 ; r=-0.652 ; r=0.652, r=0.652 ; r=-0.585)$. Other landscape elements like flowers and activities had correlations with decreased diastolic blood pressure in early summer and spring, respectively $(r=-0.532 ; r=-0.562)$. In spring, people and activity had correlations with decreased heart rates $(r=-0.693 ; r=-0.671)$. In early summer, water had a correlation with decreased heart rates $(r=-0.585)$. Moreover, a sense of tranquility had correlations with increased vigor-activity and decreased state anxiety in early summer $(r=-0.732 ; r=-0.759)$. Spatial view during park therapy such as "bird's eye view" had correlations with decreased confusion-bewilderment in early summer, increased vigor-activity, and decreased TMD in spring $(r=-0.547 ; r=0.518 ; r=-0.541)$. Further, sideway view had correlations with decreased state anxiety in early summer $(r=-0.723)$. Only "surrounding place" correlated with decreased tension-anxiety in spring $(r=-0.573)$.

To obtain complete landscape images and investigate seasonal verbal data, we applied quantitative content analysis. The co-occurrence network analysis showed the centrality of the node. The terms of the highest degree centrality found during seasonal park therapy were "to see" and "to bloom" (Figure 14). In the winter, the term "good feeling" was strongly associated with "forest bath," "nature," "large," "flower bed," "bench," "pleasant," "one," "every month," "time," and "all." In spring, the term "cherry blossom" was associated with "cherry blossom viewing," "photography," "exercise," "today," "to enter," "few steps," "to take," and "grandchild." In the summer, the term "grass" was associated with "new edge," "impressive," "landscape," "to play," "under the tree," and "to grow" (Figure 15).

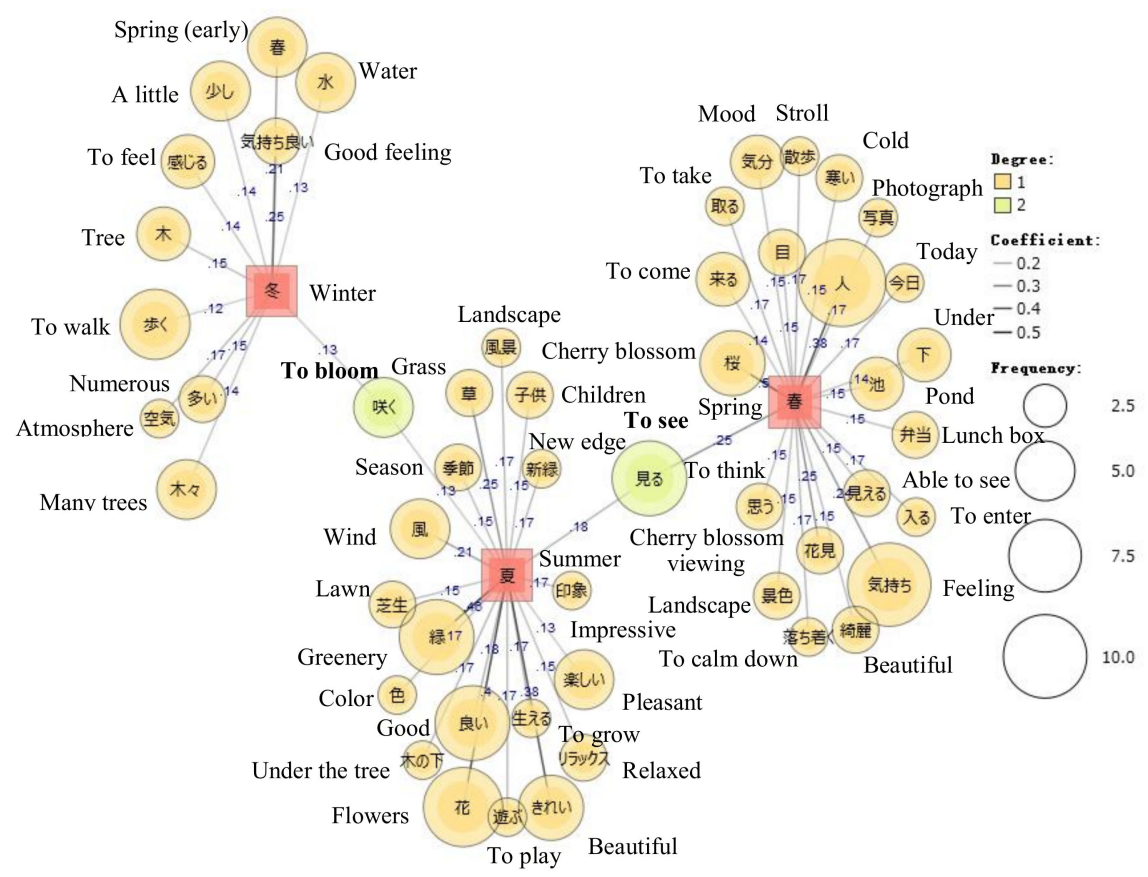

Figure 14. Seasonal co-occurrence network of park therapy images. 
Table 9. Seasonal components of park therapy images.

\begin{tabular}{|c|c|c|c|c|c|c|c|c|c|c|c|}
\hline \multirow{3}{*}{ Season } & \multicolumn{9}{|c|}{ Linguistic Knowledge } & \multirow{3}{*}{$\begin{array}{c}\text { Self-Orientation } \\
\mathrm{Sp}\end{array}$} & \multirow{3}{*}{$\begin{array}{c}\begin{array}{c}\text { Social } \\
\text { Meaning }\end{array} \\
\text { Rs } \\
\end{array}$} \\
\hline & \multicolumn{6}{|c|}{ Landscape Element (\%) } & \multicolumn{3}{|c|}{ Therapeutic Feeling (\%) } & & \\
\hline & Gr & $\operatorname{Tr}$ & Wa & La & Ac & $\mathrm{Pe}$ & Co & $\operatorname{Re}$ & $\mathrm{Br}$ & & \\
\hline Winter & 0 & 50 & 33.3 & 0 & 0 & 16.7 & 25 & 41.7 & 0 & 8.3 & 8.3 \\
\hline Spring & 33.3 & 8.3 & 75 & 0 & 25 & 41.7 & 0 & 0 & 0 & 50 & 58.3 \\
\hline Summer & 58.3 & 0 & 25 & 25 & 0 & 0 & 0 & 8.3 & 25 & 16.7 & 16.7 \\
\hline$P$-value & $0.008 * *$ & $0.004 * *$ & $0.031 *$ & $0.038 *$ & $0.038 *$ & 0.034 * & $0.038 *$ & $0.015 *$ & $0.038 *$ & $0.045^{*}$ & $0.014 *$ \\
\hline
\end{tabular}

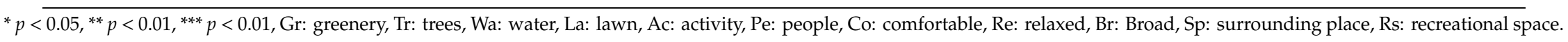

Table 10. Matrix of correlation of park therapy images and physiological-psychological responses.

\begin{tabular}{|c|c|c|c|c|c|c|c|c|c|c|c|}
\hline \multirow{3}{*}{\multicolumn{2}{|c|}{ Physiological/ PsychologicalResponses }} & \multicolumn{7}{|c|}{ Linguistic Knowledge } & \multirow{2}{*}{\multicolumn{2}{|c|}{ Spatial View }} & \multirow{3}{*}{$\begin{array}{c}\text { Self-Orientation } \\
\mathrm{Sp}\end{array}$} \\
\hline & & \multirow[b]{2}{*}{ Gr } & \multicolumn{5}{|c|}{ Landscape Element } & \multirow{2}{*}{$\begin{array}{c}\begin{array}{c}\text { Therapeutic } \\
\text { Feeling }\end{array} \\
\mathrm{Qu}\end{array}$} & & & \\
\hline & & & Fl & Ac & Wa & $\mathbf{B i}$ & $\mathrm{Pe}$ & & $\mathrm{Bv}$ & Sv & \\
\hline Heart rate & & - & - & $\mathrm{O}^{*}$ & $\Delta^{*}$ & $\square^{*}$ & $\mathrm{O}^{* *}$ & - & - & - & - \\
\hline \multirow{2}{*}{ Blood pressure } & $\begin{array}{l}\text { Systolic blood } \\
\text { pressure }\end{array}$ & - & - & - & - & $\mathrm{o}^{*}$ & - & - & - & - & - \\
\hline & $\begin{array}{l}\text { Diastolic blood } \\
\text { pressure }\end{array}$ & - & $\Delta^{*}$ & $\mathrm{o}^{*}$ & - & - & - & - & - & - & - \\
\hline \multirow{4}{*}{ Mood state } & Confusion-bewilderment & - & - & - & - & - & - & - & $\Delta^{*}$ & - & - \\
\hline & Tension-anxiety & - & - & - & - & - & - & - & - & - & $\mathrm{O}^{*}$ \\
\hline & Vigor-activity & $\mathrm{o}^{*}$ & - & - & - & $\mathrm{o}^{*}$ & - & $\Delta^{* *}$ & $\mathrm{o}^{*}$ & - & - \\
\hline & $\begin{array}{l}\text { Total Mood } \\
\text { Disturbance }\end{array}$ & - & - & - & - & $\mathrm{o}^{*}$ & - & - & $\mathrm{O}^{*}$ & - & - \\
\hline \multicolumn{2}{|c|}{ State anxiety } & - & - & - & - & $\mathrm{o}^{*}$ & - & $\Delta^{* *}$ & - & $\Delta^{* *}$ & - \\
\hline
\end{tabular}

${ }^{*} p<0.05,{ }^{* *} p<0.01,{ }^{* * *} p<0.01$, Gr: greenery, Fl: flower, Ac: activity, Wa: water, Bi: bird, Pe: people, Qu: quiet, Bv: bird's eye view, Sv: sideway view, Sp: surrounding place, $\square$ : winter, o: spring, $\Delta$ : summer. 


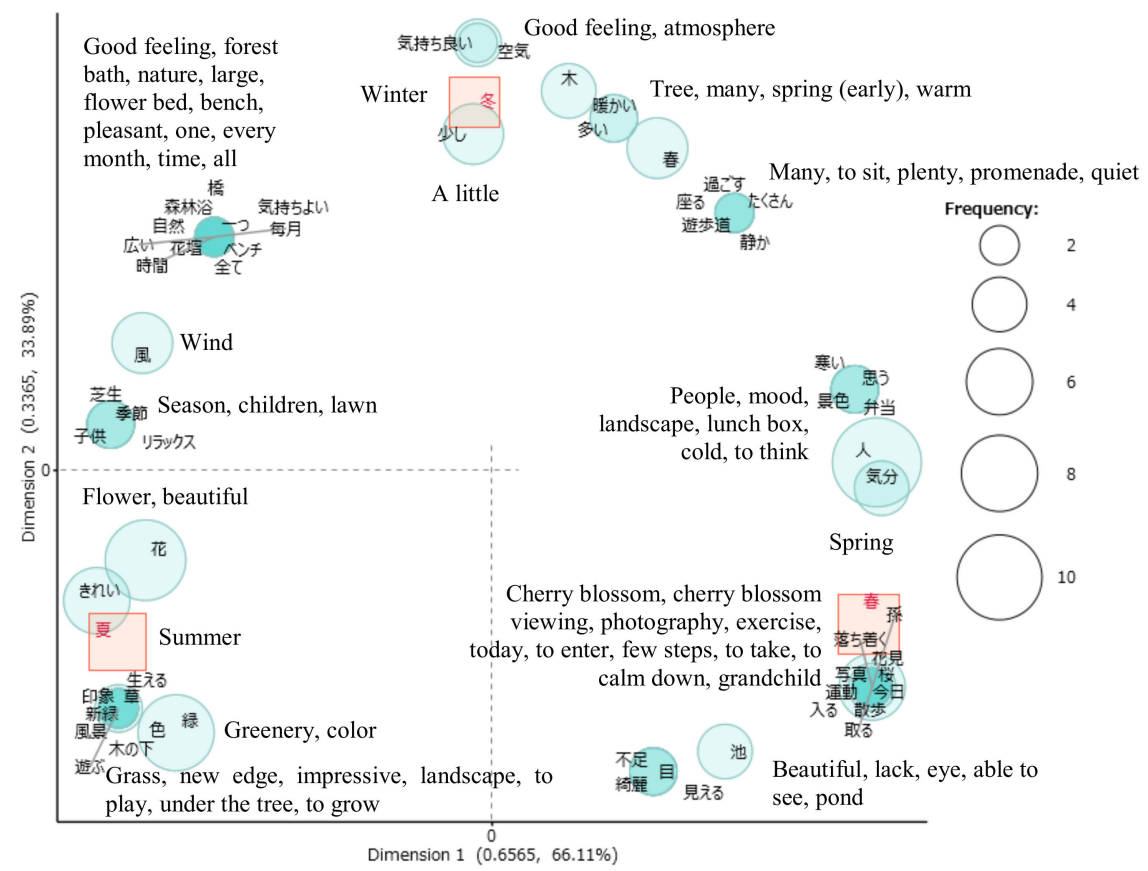

Figure 15. Seasonal correspondence analysis of park therapy images.

\section{Discussion}

This study elucidated the physiological and psychological effects among middle-aged and older adults after taking brief walks through an urban park, sketching park therapy images, and deducing correlations between park therapy images and physiological-psychological responses during winter, spring, and early summer. The main findings indicated that, compared to city walking, participants experienced a lower heart rate after 11-min of walking in an urban park in spring and 15-min of walking in winter and early summer. Further, participants experienced lower blood pressure after 11-min of walking in spring. In spring, a higher elevation in positive mood of vigor-activity was detected. Lower negative mood of confusion-bewilderment was detected in winter and early summer. Lower depression-dejection and total mood disturbance were found in winter and spring. Lower anger-hostility, fatigue-inertia, and tension-anxiety were found in early summer. Lower state anxiety was found in all seasons. In winter, a notable elevation in positive mood (vigor-activity), decline in negative mood (fatigue-inertia), total mood disturbance, and state anxiety was only noted with post-walking compared with pre-walking.

These results were compared with those of a prior study in which participants viewed urban parks. The proportion of participants who exhibited positive physiological responses in heart rate was higher while walking in urban parks $(66.7 \%)$ than viewing them $(16.47 \%)$ in both spring and summer; still, no significant difference was found. The proportion of participants who exhibited positive physiological responses in systolic and diastolic blood pressures was significantly higher while walking urban parks in spring $(91.7 \%)$, as opposed to viewing $(83.3 \%)$. This was also the case for summer (75\%, 50\%, 66.7\%, respectively). Again, there was no significant difference. In previous forest therapy studies on middle-aged hypertensive males, heart rate was significantly lower while walking [39] and viewing a forest landscape than those in a city area [17]. Heart rate was lower while viewing a forest landscape than while walking. This indicated that viewing a forest landscape could serve higher immense comfort than walking in a forest landscape. This indication was partly consistent with the current study results on middle-aged and older adults. Moreover, the proportion of participants who exhibited positive psychological responses in total mood disturbance was higher while walking in the spring $(91.7 \%)$ than while viewing $(66.7 \%)$, and equal in summer. The proportion of participants who exhibited positive psychological responses in state anxiety was higher when viewing urban parks 
$(75 \%, 91.7 \%)$ than walking $(66.7 \%, 75 \%)$ in spring and early summer, respectively. Nevertheless, a significant difference was not found in a psychological response comparison. Previous forest therapy studies have reinforced that, for middle-aged hypertensive males, negative mood scores were lower while positive mood scores were higher when viewing a forest than walking in a city on middle-aged hypertensive males [39]. This is also the case for total mood disturbance on young males [40] and state anxiety on young women [9].

In winter, spring, and early summer, a brief walk in an urban park was more beneficial for cardiovascular health than walking in the city. Forest and park therapy studies have informed consistent results regarding decreased blood pressure [2-4,24] and heart rates [5-8,20]. Moreover, the activity of viewing blooming flowers is called flower therapy, which is proven to increase the high-frequency component of heart rate variability [41]. As in winter, results of blood pressure measurements in early summer were not significant while walking in the two environments, although lower blood pressure after walking in the urban park compared with those in the city area was observed. This could be due to environmental stimuli (e.g., typical landscape characteristics, lower temperature in winter, intensity of sunlight in summer, visitor walking through, park staff's maintenance activity, as well as immediate activity and noise) that might impact blood pressure measurement $[3,42]$.

According to two psychological evaluations, walking in urban parks lead to psychological health in all seasons. We found only positive moods of vigor-activity in the urban park during spring. In winter and early summer, we found decreased negative moods of confusion-bewilderment. In winter and spring, we found depression-dejection and total mood disturbance. In early summer we found anger-hostility, fatigue-inertia, and tension-anxiety. We found state anxiety in all seasons. The significant mood changes in fatigue-inertia, vigor-activity, and total mood disturbance were discovered post-walking compared with pre-walking in the urban park during winter. Previous forest and park therapy studies described a significant difference in moods (e.g., decreased negative moods, increased positive mood) and state anxiety after walking in urban parks [6-10,16,42]. More park stimulations experienced in spring such as walking, viewing cherry blossoms, ponds, and forests, as well as watching people's activities under cherry trees, led to higher positive moods than those in winter and early summer $[7,16,24,42]$. These results indicate that a 15 -min walk in winter and early summer and an 11-min walk in spring have physiological and psychological merits for middle-aged and older adults, which were congruent with previous studies implemented in other sites in Japan, China, and Taiwan [15-20,43].

By analyzing verbal and visual LIST data, prominent landscape elements were detected through brief winter, spring, and early summer walks. During winter, park therapy images related to "trees," "comfort" and "relaxation". During spring, park therapy images related to "water," "activity," "people," "surrounding place," and "recreational space." During early summer, park therapy images related to "greenery," "lawn," and "broadness." The most dynamic landscape components were plants with their shifting colors and quantities of leaves throughout the seasons. Trees $(50 \%)$ were the most sketched landscape element in winter and greenery $(58.3 \%)$ in early summer. This seasonal dynamic determines characteristics of park coloring in which optical and climatic factors act as specific filters that influence the perception of park landscape coloring [44]. Through a park therapy image analysis, relationships between perceived landscapes and participants' physiological-psychological responses became clear. The existence of birds in the urban park was a factor that had correlations with most physiological and psychological benefits. According to Ratcliffe et al., bird songs and calls were found as one of the natural sounds most commonly associated with stress recovery and attention restoration [45]. In a further quantitative text analysis, "good feeling" was the centrality of landscape images in winter, "cherry blossom" in spring, and "greenery" in early summer. These texts had the highest centrality degree, with the interconnected words playing an essential role in the people-nature relationship [46]. In spring, various stimuli influenced the number of text mining results. Subjects used their senses to describe activities, landscape elements, and impressions of the park therapy program. Descriptive verbal data stressed that text mining results were consistent with the results of verbal and visual 
data keywords and could detect the centrality of landscape images. These findings provide scientific evidence that urban green spaces do not only have social and environmental benefits but also play a vital role in both mental and physical health [47,48].

This study proves that walking, even for a brief time, through deciduous trees, cherry blossoms, and fresh greenery led to physiological and psychological relaxation, as well as landscape appreciation. As many urban park studies indicate, simple physical activities such as walking in a nearby urban park can decrease feelings of anger-hostility, confusion-bewilderment, depression-dejection, fatigue-inertia, tension-anxiety, total mood disturbance, and state anxiety, and increase vigor-activity. The various physiological and psychological benefits of walking might be stimulated by physical variables (e.g., temperature, relative humidity) and seasonal landscape characteristics such as greenery, flowers, birds, physical activity, tranquility, middle distance in viewing scenery, and dense surrounding vegetation. This study's findings suggest that walking in an urban park during different seasons could be considered to enhance senior citizen's quality of life. These findings might be useful for park therapy road design considerations, especially in feature of park landscape. These considerations include (1) accessible walking courses among tree stands or thinned forest; (2) middle ground as suitable views of distance zone; and (3) diversity of seasonal landscape changes (e.g., greenery, flowers, birds, water, lawn, physical activity), so that the park user can feel tranquil.

Our study has several limitations. First, the main limitation is the substantial risk of "memory effects" with the tests (walking and seated viewing) carried out over the same period. Second, we had a limited number of participants for our walking experiment during each season. Therefore, further studies that feature more middle-aged and older adults and a randomized controlled trial of city citizens is necessary to confirm our findings. Third, this study was conducted to clarify the physiological and psychological effects of walking in urban parks with seasonal landscape characteristics. Because experiments were conducted on the same walking course with the same walking duration during winter and early summer, and a different walking course with a different walking duration during spring, differences might have influenced the results. Fourth, parameters applied only physiological parameters of blood pressure and heart rate, psychological parameters of POMS and STAI, and landscape perception of LIST. Another parameter, such as landscape preference using geo-tagged photographs or virtual reality (VR) method could be integrated into physiological and psychological studies for advanced findings. All limitations must be addressed in future research.

\section{Conclusions}

This study provided significant scientific evidence for the physiological and psychological relaxation effects of walking in urban parks, correlating park therapy images accordingly. Walking in urban parks resulted in: (1) significant decreases in heart rates during winter, spring, and early summer; (2) significant decreases in blood pressure during spring; (3) significant decreases in confusion-bewilderment in winter and early summer, depression-dejection in winter and spring, and anger-hostility, fatigue-inertia, and tension-anxiety only in early summer; (4) significant decreases in total mood disturbance in winter and spring; (5) significant increases in vigor-activity in spring; and (6) significant decreases in state anxiety in winter, spring, and early summer. In winter, park therapy images exhibited the people-nature relationship with "trees," "relaxation," and "comfort," describing good feelings as psychological benefits of park therapy. In spring, park therapy image exhibited landscape elements, self-orientation, and social meaning of place, namely "water," "activity," "people," "surrounding place," and "recreational space," wherein cherry blossom-viewing became significant as a traditional Japanese way of appreciating nature. In early summer, park therapy image exhibited landscape openness such as "greenery," "lawn," and "broadness," in which beautiful fresh greenery, thick grass, and green lawn display intense color. The correlation among park therapy images and physiological-psychological responses were high in "birds" as indicator creatures in landscapes. A "bird's eye view" was a middle distance to view the landscapes. Greenery was an important park feature to experience relaxation. Other components such as flowers, activity, water, people existence, 
tranquility, sideways view, and surrounding place were also important. Evidence-based special features of the park landscape include: (1) accessible walking course among tree stands or thinned forest; (2) middle ground as suitable views of distance zone; and (3) diversity of seasonal landscape changes (e.g., greenery, flowers, birds, water, lawn, physical activity) are suggested for park therapy roads. Park images during the experimental period provide impressive and preferable park elements, suitable views, orientation, and sense of place in the park. Furthermore, our findings also propose participatory planning and design through middle-aged and older adults' perception and experience of park therapy for sustainable landscape development, especially senior citizen-friendly urban parks.

Author Contributions: Conceptualization, P.I.P. and K.F.; methodology, P.I.P. and K.F.; formal analysis, P.I.P. and Q.X.; funding acquisition, K.F.; investigation, P.I.P., Q.X. and K.F.; data curation, P.I.P. and Q.X.; resources, P.I.P., Q.X. and K.F.; software, P.I.P., Q.X. and K.F.; writing—original draft preparation, P.I.P.; writing-review and editing, P.I.P. and K.F.; visualization, P.I.P. and Q.X.; supervision, K.F.; project administration, P.I.P. and Q.X. All authors have read and agreed to the published version of the manuscript.

Funding: This study is funded by JSPS KAKENHI, grant number JP17K08179.

Acknowledgments: We thank Takahide Kagawa of Forestry and Forest Products Research Institute for support and discussions on how forest therapy works; Aya Utsumi of Forest and Park for the 21st Century for help and support in schedule, communication, and room usage; Takayoshi Enomoto of NPO Matsudo Creative, as well as Landscape Planning Laboratory members: Mao Yingming, Fumeng Zhang, Hanqiu Zhang, Xie Zijiao, Lu Tingyu, Luo Shixian, Mai Uemura, and Indira Dwi Imara for coordination on experimental days.

Conflicts of Interest: The authors declare no conflict of interest.

\section{References}

1. Li, Q. Effect of forest bathing trips on human immune function. Environ. Health Prev. Med. 2010, 15, 9-17. [CrossRef] [PubMed]

2. Park, B.J.; Tsunetsugu, Y.; Kasetani, T.; Morikawa, T.; Kagawa, T.; Miyazaki, Y. Physiological effects of forest recreation in a young conifer forest in Hinokage Town, Japan. Silva Fenn. 2009, 43, 291-301. [CrossRef]

3. Lee, J.; Park, B.J.; Tsunetsugu, Y.; Kagawa, T.; Miyazaki, Y. Restorative effects of viewing real forest landscapes, based on a comparison with urban landscapes. Scand. J. For. Res. 2009, 24, 227-234. [CrossRef]

4. Tsunetsugu, Y.; Lee, J.; Park, B.; Tyrvainen, L.; Kagawa, T.; Miyazaki, Y. Physiological and psychological effects of viewing urban forest landscapes assessed by multiple measurements. Landsc. Urban Plan. 2013, 113, 90-93. [CrossRef]

5. Matsuba, N.; Lee, J.; Park, B.; Lee, M.; Song, C.; Miyazaki, Y. Physiological effects of walking in Shinjuku Gyouen, a large-scale urban green area. Jpn. J. Physiol. Anthropol. 2011, 16, 133-139.

6. Song, C.; Joung, D.; Ikei, H.; Igarashi, M.; Aga, M.; Park, B.J.; Miwa, M.; Takagaki, M.; Miyazaki, Y. Physiological and psychological effects of walking on young males in urban parks in winter. J. Physiol. Anthropol. 2013, 32, 18. [CrossRef] [PubMed]

7. Song, C.; Ikei, H.; Igarashi, M.; Miwa, M.; Takagaki, M.; Miyazaki, Y. Physiological and psychological responses of young males during spring-time walks in urban parks. J. Physiol. Anthropol. 2014, 33, 8. [CrossRef]

8. Song, C.; Ikei, H.; Igarashi, M.; Takagaki, M.; Miyazaki, Y. Physiological and psychological effects of a walk in urban parks in fall. Int. J. Environ. Res. Public Health 2015, 12, 14216-14228. [CrossRef]

9. Song, C.; Ikei, H.; Kagawa, T.; Miyazaki, Y. Physiological and psychological effects of viewing forests on young women. Int. J. Environ. Res. Public Health 2019, 10, 635. [CrossRef]

10. Song, C.; Ikei, H.; Kagawa, T.; Miyazaki, Y. Effects of walking in a forest on young women. Int. J. Environ. Res. Public Health 2019, 16, 229. [CrossRef]

11. Park, B.J.; Tsunetsugu, Y.; Kasetani, T.; Hirano, H.; Kagawa, T.; Sato, M.; Miyazaki, Y. Physiological Effects of Shinrin-yoku (Taking in the Atmosphere of the Forest)-Using Salivary Cortisol and Cerebral Activity as Indicators. J. Physiol. Anthropol. 2007, 26, 123-128. [CrossRef] [PubMed]

12. Takayama, N.; Korpela, K.; Lee, J.; Morikawa, T.; Tsunetsugu, Y.; Park, B.J.; Li, Q.; Tyrväinen, L.; Miyazaki, Y.; Kagawa, T. Emotional, restorative and vitalizing effects of forest and urban environments at four sites in Japan. Int. J. Environ. Res. Public Health 2014, 11, 7207-7230. [CrossRef] [PubMed] 
13. Chen, H.; Yu, C.; Lee, H. The effects of forest bathing on stress recovery: Evidence from middle-aged females of Taiwan. Forest 2018, 9, 403. [CrossRef]

14. Ochiai, H.; Ikei, H.; Song, C.; Kobayashi, M.; Takamatsu, A.; Miura, T.; Kagawa, T.; Li, Q.; Kumeda, S.; Imai, M.; et al. Physiological and psychological effects of forest therapy on middle-age males with high-normal blood pressure. Int. J. Environ. Res. Public Health 2015, 12, 2521-2531.

15. Li, Q.; Kobayashi, M.; Kumeda, S.; Ochiai, T.; Miura, T.; Kagawa, T.; Imai, M.; Wang, Z.; Otsuka, T.; Kawada, T. Effects forest bathing on cardiovascular and metabolic parameters in middle-aged males. Evid. Based Complement. Altern. Med. 2016, 2016, 2587381. [CrossRef]

16. Yu, C.; Lin, C.; Tsai, M.; Tsai, Y.; Chen, C. Effects on short forest bathing program on autonomic nervous system activity and mood states in middle-aged and elderly individuals. Int. J. Environ. Res. Public Health 2017, 14, 897. [CrossRef]

17. Song, C.; Ikei, H.; Kobayashi, M.; Miura, T.; Li, Q.; Kagawa, T.; Kumeda, S.; Imai, M.; Miyazaki, Y. Effect of viewing forest landscape on middle-aged hypertensive men. Urban For. Urban Green. 2017, 21, $247-252$. [CrossRef]

18. Matsunaga, K.; Park, B.; Kobayashi, H.; Miyazaki, Y. Physiologically relaxing effect of a hospital rooftop forest on older women requiring care. J. Am. Geriatr. Soc. 2011, 59, 2162-2163. [CrossRef]

19. Goto, S.; Gianfagia, T.J.; Munafo, J.P.; Fujii, E.; Shen, X.; Sun, M.; Shi, B.E.; Liu, C.; Hamano, H.; Herrup, K. The power of traditional design techniques: The effects of viewing a Japanese garden on individuals with cognitive impairment. Health Environ. Res. Des. J. 2016, 10, 74-86. [CrossRef]

20. Igarashi, M.; Miwa, M.; Ikei, H.; Song, C.; Takagaki, M.; Miyazaki, Y. Physiological and psychological effects of viewing a kiwifruit (Actinidia deliciosa 'Hayward') orchard landscape in summer in Japan. Int. J. Environ. Res. Public Health 2015, 12, 6657-6668. [CrossRef]

21. Hofmann, M.; Young, C.; Binz, T.M.; Baumgartner, M.R.; Bauer, N. Contact to nature benefits health: Mixed effectiveness of different mechanisms. Int. J. Environ. Res. Public Health 2018, 15, 31. [CrossRef] [PubMed]

22. Ng, K.S.T.; Sia, A.; Ng, M.K.W.; Tan, C.T.Y.; Chan, H.Y.; Tan, C.H.; Rawtaer, I.; Feng, L.; Mahendran, R.; Larbi, A.; et al. Effects of horticultural therapy on Asian older adults: A randomized controlled trial. Int. J. Environ. Res. Public Health 2018, 15, 1705. [CrossRef] [PubMed]

23. Ojala, A.; Korpela, K.; Tyrväinen, L.; Tiittanen, P.; Lanki, T. Restorative effects of urban green environments and the role of urban-nature orientedness and noise sensitivity: A field experiment. Health Place 2019, 55, 59-70. [CrossRef] [PubMed]

24. Pratiwi, P.I.; Xiang, Q.; Furuya, K. Physiological and psychological effects of viewing urban parks in different seasons in adults. Int. J. Environ. Res. Public Health 2019, 16, 4279. [CrossRef]

25. Uijtdewilligen, L.; Waters, C.N.H.; Aw, S.; Wong, M.L.; Sia, A.; Ramiah, A.; Wong, M.; Riemenschneider, F.M. The park prescription study: Development of a community-based physical activity intervention for a multi-ethnic Asian population. PLoS ONE 2019, 14, e0218247. [CrossRef]

26. Ueda, H. A Study on Construction of Landscape Image Sketching Technique. J. City Plan. Inst. Jpn. 2009, 44, $37-42$.

27. Ueda, H.; Nakajima, T.; Takayama, N.; Petrova, E.; Matsushima, H.; Furuya, K.; Aoki, Y. Landscape image sketches of forests in Japan and Russia. For. Policy Econ. 2012, 19, 20-30. [CrossRef]

28. Pratiwi, P.I.; Sulistyantara, B.; Gunawan, A.; Furuya, K. A comparative study on the perception of forest landscape using LIST method between university students of Japan and Indonesia. J. Manaj. Hutan Trop. 2014, 20, 167-178. [CrossRef]

29. Kohori, F.; Furuya, K. The characteristics of Indonesian open space image based on the space configuration. J. Jpn. Inst. Landsc. Arch. 2017, 80, 579-584. [CrossRef]

30. Ueda, H.; Takayama, N. Study on the spatial conditions constituting the image of bathing in a forest atmosphere. Landsc. Res. Jpn. Online 2011, 4, 1-6. [CrossRef]

31. Lee, J.; Park, B.J.; Ohira, T.; Kagawa, T.; Miyazaki, Y. Acute effects of exposure to a traditional rural environment on urban dwellers: A crossover field study in terraced farmland. Int. J. Environ. Res. Public Health 2015, 12, 1874-1893. [CrossRef] [PubMed]

32. Takayama, N.; Fujiwara, A.; Saito, H.; Horiuchi, M. Management effectiveness of a secondary coniferous forest for landscape appreciation and psychological restoration. Int. J. Environ. Res. Public Health 2017, 14, 800. [CrossRef] [PubMed] 
33. Heuchert, J.P.; McNair, D.M. Profile of Mood States, 2nd ed.; POMS 2; Multi-Health Systems Inc.: North Tonawanda, NY, USA, 2012.

34. Hashim, H.A. Application of Psychometrics in Sports and Exercise; Universiti Sains Malaysia: Gelugor, Pulau Pinang, Malaysia, 2018.

35. Konuma, H.; Hirose, H.; Yokoyama, K. Relationship of the Japanese translation of the profile of mood states second edition (POMS $2^{\circledR}$ ) to the first edit ion (POMS ${ }^{\circledR}$ ). Juntendo Med. J. 2015, 61, 517-519. [CrossRef]

36. Spielberger, C.D.; Sarason, I.G. Stress and Anxiety; Hemisphere Publishing Corporation: New York, NY, USA, 1985; Volume 9.

37. Iwata, N.; Mishima, N.; Shimizu, T.; Mizoue, T.; Fukuhara, M.; Hidano, T.; Spielberger, C.D. The Japanese adaptation of the STAI form $\mathrm{Y}$ in Japanese working adults-The presence or absence of anxiety. Ind. Health 1998, 36, 8-13. [CrossRef]

38. Higuchi, K. Quantitative Text Analysis for Social Researchers: A Contribution to Content Analysis; Nakanishiya Publishing: Kyoto, Japan, 2014.

39. Song, C.; Ikei, H.; Kobayashi, M.; Miura, T.; Taue, M.; Kagawa, T.; Li, Q.; Kumeda, S.; Imai, M.; Miyazaki, Y. Effect of forest walking on autonomic nervous system activity in middle-aged hypertensive individuals: A pilot study. Int. J. Environ. Res. Public Health 2015, 12, 2687-2699. [CrossRef] [PubMed]

40. Park, B.J.; Furuya, K.; Kasetani, T.; Takayama, N.; Kagawa, T.; Miyazaki, Y. Relationship between psychological responses and physical environments in forest settings. Landsc. Urban Plan. 2011, 102, 24-32. [CrossRef]

41. Ikei, H.; Komatsu, M.; Song, C.; Himoro, E.; Miyazaki, Y. The physiological and psychological relaxing effects of viewing rose flowers in office workers. J. Physiol. Anthropol. 2014, 33, 6. [CrossRef] [PubMed]

42. Lyu, B.; Zeng, C.; Deng, S.; Liu, S.; Jiang, M.; Li, N.; Wei, L.; Yu, Y.; Chen, Q. Bamboo forest therapy contributes to the regulation of psychological responses. J. For. Res. 2019, 24, 61-70. [CrossRef]

43. Mao, G.; Cao, Y.; Wang, B.; Wang, S.; Chen, Z.; Wang, J.; Xing, W.; Ren, X.; Lv, X.; Dong, J.; et al. The salutary influence of forest bathing on elderly patients with chronic heart failure. Int. J. Environ. Res. Public Health 2017, 14, 368. [CrossRef]

44. Oleksiichenko, N.; Gatalska, N.V.; Mavko, M. The colour-forming components of park landscape and the factors that influence the human perception of the landscape colouring. Theor. Empir. Res. Urban Manag. 2018, 13, 38-52.

45. Ratcliffe, E.; Gatersleben, B.; Sowden, P.T. Bird sounds and their contributions to perceived attention restoration and stress recovery. J. Environ. Psychol. 2013, 36, 221-228. [CrossRef]

46. Min, K.; Jun, B.; Lee, J.; Kim, H.; Furuya, K. Analysis of environmental issues with an application of civil complaints: The case of Shiheung City, Republic of Korea. Int. J. Environ. Res. Public Health 2019, 16, 1018. [CrossRef] [PubMed]

47. Diener, E.; Biswas-Diener, R. Epilogue: About the science of happiness. In Happiness: Unlocking the Mysteries of Psychological Wealth; Blackwell Publishing Ltd.: Oxford, UK, 2008; pp. 244-253.

48. Abdullah, Y.A.; Zulkifli, F.L. Concept and theories of happiness of population in urban neighbourhoods. Environ. Behav. Proc. J. 2016, 1, 260-268. [CrossRef]

(C) 2020 by the authors. Licensee MDPI, Basel, Switzerland. This article is an open access article distributed under the terms and conditions of the Creative Commons Attribution (CC BY) license (http://creativecommons.org/licenses/by/4.0/). 